\title{
2. CALCAREOUS NANNOFOSSIL AND PLANKTONIC FORAMINIFER BIOSTRATIGRAPHY OF HOLE 810C (SHATSKY RISE, NORTHWESTERN PACIFIC) ${ }^{1}$
}

\author{
Isabella Premoli Silva, ${ }^{2}$ Davide Castradori, ${ }^{2}$ and Silvia Spezzaferri ${ }^{2}$
}

\begin{abstract}
The $136 \mathrm{~m}$ of calcareous oozes recovered in Hole $810 \mathrm{C}$ span the interval from upper Maastrichtian to middle Pleistocene. Three major hiatuses interrupt the sequence, with the topmost part of the Maastrichtian through the entire lower Paleocene, most of the lower Eocene, and the entire middle Eocene through most of the middle Miocene missing. Severe reworking and displacement affected the lower part of the succession from the Maastrichtian through the middle Miocene. Reworking and displacement gradually decreased in the upper portion. Calcareous nannofossil biostratigraphy enabled us to calibrate precisely the nearly complete magnetic reversal sequence of the Pliocene to the late Pleistocene. Two minor hiatuses detected by calcareous nannofossils across the Pliocene/Pleistocene boundary and in the upper lower Pleistocene, respectively, resulted in shortening of the Olduvai and Jaramillo Events within the Matuyama Chron of the magnetic reversal sequence.
\end{abstract}

\section{INTRODUCTION}

\section{Site Description}

Hole $810 \mathrm{C}$ was drilled on the Shatsky Rise $\left(32^{\circ} 25.40^{\prime} \mathrm{N}\right.$, $157^{\circ} 50.74^{\prime} \mathrm{E}$ ) at a water depth of $2623.0 \mathrm{~m}$ (Fig. 1). Fifteen advanced hydraulic piston cores (APC) and a single extended core barrel (XCB) were raised from Hole $810 \mathrm{C}$ for a total recovery rate of $100 \%$. The sedimentary sequence (Fig. 2) consists of $4.2 \mathrm{~m}$ of nannofossil ooze with common to abundant siliceous microfossils (Unit I, $0.0-4.2 \mathrm{~m}$ below seafloor, or mbsf), $71.8 \mathrm{~m}$ of nannofossil ooze with rare ash beds and isolated pumice pebbles (Unit II, 4.2-76.0 mbsf), $23.5 \mathrm{~m}$ of nannofossil ooze and calcareous clay in rhythmically alternating bands (Unit III, 76.0-99.5 mbsf), $13.8 \mathrm{~m}$ of nannofossil ooze with much bioturbation and rich in large-sized nannofossils (Unit IV, 99.5-113.3 mbsf), and $22.8 \mathrm{~m}$ of firm nannofossil ooze with foraminifers and chert (Unit V, 113.3-136.1 mbsf). Drilling disturbances occur from Section 132-810C-12H-2 through Core 132-810C-13H, because of anomalous contacts marked by major hiatuses, and in Core 132-810C-16X, possibly because of the presence of chert nodules.

Preliminary investigations conducted aboard ship on planktonic foraminifers revealed only that the recovered sequence spanned an interval from Maastrichtian through Holocene. It was interrupted and/or disturbed by the presence of several hiatuses, condensed sequences, and reworking events (Storms, Natland, et al., 1991).

The main stratigraphic hiatuses previously detected and confirmed by this work are as follows:

1. Between Sample 132-810C-13H-5, 41-43 cm, and Sample $132-810 \mathrm{C}-13 \mathrm{H}-5,21-22 \mathrm{~cm}$, where we can observe the contact between sediments of early late Paleocene and late Maastrichtian age.

2. Between Sample 132-810C-13H-2, 21-22 cm, and Sample $132-810 \mathrm{C}-13 \mathrm{H}-2,7-9 \mathrm{~cm}$, where sediments of late early Eocene age directly rest on a sequence of early late Paleocene age.

3. Between Sample 132-810C-12H-2, 120-122 cm, and Sample $132-810 \mathrm{C}-12 \mathrm{H}-2,75-77 \mathrm{~cm}$, where the middle Miocene lies on top of the upper lower Eocene.

This paper deals with the detailed biostratigraphic investigation of both calcareous nannofossils and planktonic foraminifers from Hole

\footnotetext{
${ }^{1}$ Natland, J.H., Storms, M.A., et al., 1993. Proc. ODP, Sci. Results, 132: College Station, TX (Ocean Drilling Program).

${ }^{2}$ Dipartimento di Scienze della Terra, Università di Milano, via Mangiagalli 34. Milano 20133, Italy.
}

810 C. D. Castradori studied the nannofossils, whereas I. Premoli Silva and S. Spezzaferri studied the planktonic foraminifers of Maastrichtian through early Eocene and of middle Miocene through late Pleistocene age, respectively.

\section{MATERIALS AND METHODS}

Sample spacing was guided by the preliminary investigations and resulted in a variable sample density for the different intervals. In general, samples were taken three per section except in Cores 132$810 \mathrm{C}-1 \mathrm{H}$ through $-3 \mathrm{H}$ and in Cores $132-810 \mathrm{C}-7 \mathrm{H}$ through $-11 \mathrm{H}$. In the latter, samples were taken one per section, whereas up to 5 samples per section were taken across the major hiatuses. Calcareous nannofossils were studied in all the collected samples, whereas planktonic foraminifer investigation was confined only to two to three samples per core in the upper part of the sequence, where assemblages are relatively monotonous. A sample volume of about $10 \mathrm{~cm}^{3}$ was used for both fossil groups.

The study of calcareous nannofossils at Hole $810 \mathrm{C}$ is based on 176 samples. For each sample a permanent smear slide was mounted with Canada balsam. Because abundance and preservation of the recovered assemblages were always sufficient, no particular technique was applied to concentrate or "clean" the biogenic fraction (e.g., centrifuge, ultrasound).

Smear slides were analyzed using an optical polarizing microscope at $1250 \times$ magnification. This methodology was chosen because it allows a relatively simple and fast sample preparation; moreover, this technique is widely used for routine biostratigraphic nannofossil analysis.

The study of calcareous nannofossils is summarized in the distribution charts of Figures 3 through 7, where a semiquantitative estimate of the abundance of single taxa is also plotted, according to the following ranking: $\mathrm{A}=$ abundant (more than 1 specimen per field of view; $1250 \times$ ); $C=$ common (at least 1 specimen in 10 fields of view); $\mathrm{F}=$ frequent (at least 1 specimen in 30 fields of view); $\mathrm{R}=$ rare (less than 1 specimen in 30 fields of view); $R R=$ very rare ( 1 or 2 specimens detected during the analysis).

All 176 samples studied yielded "abundant" nannofloras (more than 20 specimens per field of view). Moreover, the distribution charts include an estimate of the overall abundance of the reworked taxa.

All samples for foraminifer study were washed in distilled water through $>250-, 250-150-$, and $150-40-\mu \mathrm{m}$ sieves, and the three fractions obtained were dried in open air in case some specimens proved to be suitable for isotopic analyses. Each sample was weighted 


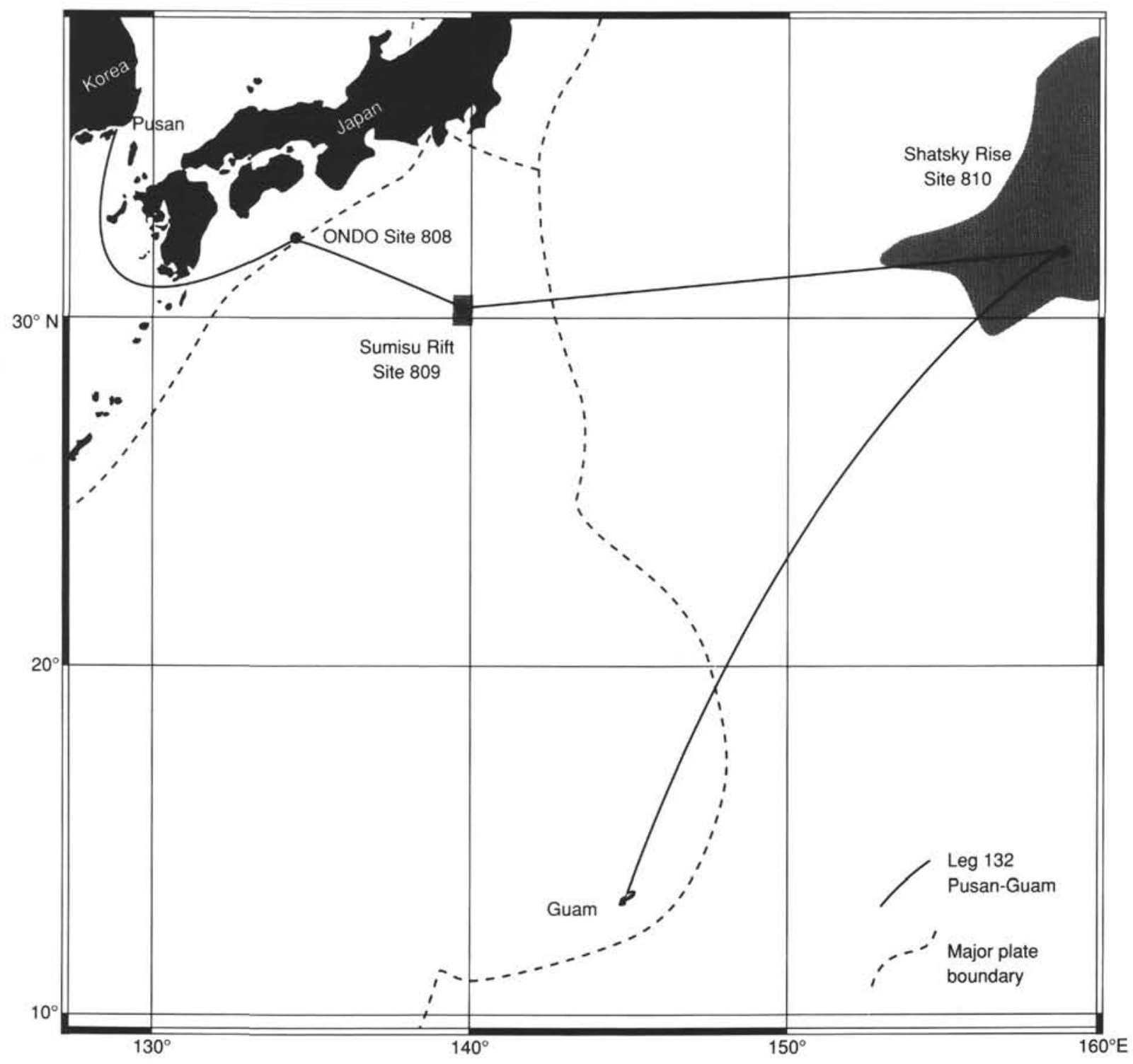

Figure 1. Location of Site 810, Shatsky Rise.

before and after washing, as were the three washed fractions. This operation was performed to determine the relationship among the fractions in the case of resedimented and/or dissolved assemblages, to prove sorting and/or degree of dissolution, respectively (Premoli Silva and Violanti, 1981; Spezzaferri, 1992). Abundance of the single species and groups, and other organic and inorganic components over the total faunas, were estimated for each fraction when possible. Five categories were distinguished and plotted in the range charts as follows: $\mathrm{VR}=$ very rare $(1-5$ specimens $) ; \mathrm{R}=\operatorname{rare}(5-10$ specimens $)$; $\mathrm{C}=$ common $(10-30$ specimens $) ; \mathrm{A}=$ abundant $(>50 \%$ of the total fauna); $\mathrm{VA}=$ very abundant (dominant).

Residues, abundance of other components, reworked and/or contaminant specimens as well as planktonic foraminifer preservation were graded with the following scales, respectively: VS = very scarce; $\mathrm{S}=$ scarce $; \mathrm{M}=$ medium abundant $\mathrm{A}=$ abundant $\mathrm{X}=$ simple presence; $\mathrm{VP}=$ very poor preservation; $\mathrm{P}=$ poor preservation; $\mathrm{M}=$ medium preservation; $\mathrm{G}=$ good preservation. Presence of inorganic components was indicated as follows: $\mathrm{qz}=$ quartz; $\mathrm{ox}=$ oxide; $\mathrm{gl}=$ glauconite; $\mathrm{v}=$ volcanic glass; $\mathrm{ch}=$ chert.

\section{BIOSTRATIGRAPHY}

On the basis of the three major hiatuses, listed in the "Introduction" (this chapter; Fig. 2), the stratigraphic sequence recovered at Hole $810 \mathrm{C}$ can be subdivided into four portions: one belonging to the Late Cretaceous (Maastrichtian), two of Paleogene age (late Paleocene and early Eocene), and one spanning the middle Miocene to Pleistocene time interval. The four intervals will be separately described in each fossil group.

\section{Calcareous Nannofossils}

Identification of nannofossil zones follows Perch-Nielsen (1981) for the Maastrichtian, Okada and Bukry (1980) for the Paleogene and Neogene, Gartner (1977) for the uppermost Pliocene and Pleistocene.

In some cases, biometric analyses have been performed by using the micrometer scale of the optical microscope. This kind of study was applied to define some taxonomic concepts and the related biostratigraphic events that are based on the absolute size of coccoliths. For 


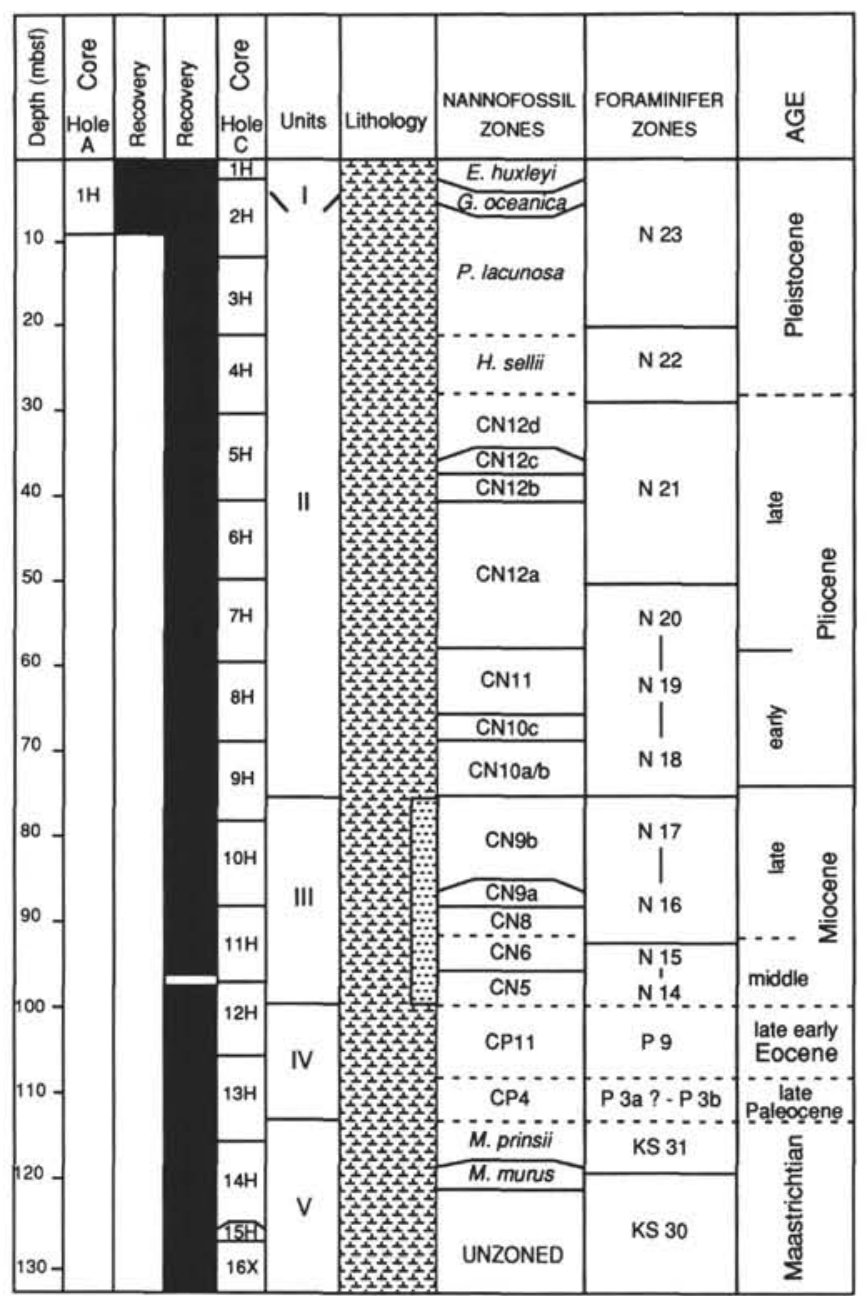

Figure 2. Lithologic log, core numbers and recovery, lithologic units, and calcareous nannofossil and planktonic foraminifer zones from Hole 810C.

what concerns the Gephyrocapsa group, a simplified taxonomy was applied for the identification of its different species. On the basis of the classifications adopted by Gartner (1977), Raffi and Rio (1979), Rio (1982), and Rio et al. (1990), among others, Gephyrocapsa spp. have been subdivided as follows: (1) G. oceanica s.l. has an open central area and a maximum length between 3.5 and $5.5 \mu \mathrm{m}$; (2) "small" Gephyrocapsa has a maximum length shorter than $3.5 \mu \mathrm{m}$; (3) Gephyrocapsa sp. 3 (sensu Rio, 1982) $(=G$. parallela), usually 4 to $6 \mu \mathrm{m}$ in size, is characterized by a bridge nearly parallel to the short axis of the ellipse; and (4) "large" Gephyrocapsa has an open central area and maximum length longer than $5.5 \mu \mathrm{m}$.

\section{Late Maastrichtian (Samples 132-810C-16X-2, 110-112 cm, to $132-810 \mathrm{C}-13 \mathrm{H}-5,41-43 \mathrm{~cm}$ )}

Starting from the base of the sequence drilled at Hole $810 \mathrm{C}$, the first 34 samples contain nannofossil assemblages belonging to the Maastrichtian. Nannofloras are always abundant, well diversified and commonly nicely preserved. Only a few samples (Fig. 3) are affected by weak dissolution. Reworking, as detectable through biostratigraphic analysis, is rare.

The lowest $10 \mathrm{~m}$ of the drilled sequence (i.e., from Sample 132$810 \mathrm{C}-16 \mathrm{X}-2,110-112 \mathrm{~cm}$, to Sample $132-810 \mathrm{C}-14 \mathrm{H}-4,25-27 \mathrm{~cm}$ ) yielded a nannofloral assemblage that could be tentatively attributed to the late Campanian-early Maastrichtian: the presence of Quadrum trifidum and Reinhardtites levis, in fact, indicates such an age.

The planktonic foraminiferal analysis, however, clearly demonstrates that the lowermost part of the stratigraphic sequence in Hole $810 \mathrm{C}$ has a late Maastrichtian age, based on the identification of the Gansserina gansseri Zone (see below). For this reason, we prefer to leave this interval unzoned with respect to calcareous nannofossils.

The first biostratigraphic datum believed reliable in Figure 3 is the first occurrence (FO) of Micula murus in Sample 132-810C-14H-3, $125-127 \mathrm{~cm}$. It is followed, some $3 \mathrm{~m}$ above, by the FO of Micula prinsii (Sample 132-810C-14H-2, 75-77 cm). These two biostratigraphic events allow us to assign an age for these samples of late Maastrichtian (Perch-Nielsen, 1981). The lower boundary of the $M$. murus Zone may be obscured by reworking, which led to dilution of the assemblages. The top of the $M$. prinsii Zone was not observed, based on the absence of Thoracosphaera spp. in the uppermost sample (Sample 132-810C-13H-5, 41-43 cm) below the hiatus.

\section{Late Paleocene (Samples 132-810C-13H-5, 21-22 cm, to} $132-810 \mathrm{C}-13 \mathrm{H}-2,21-22 \mathrm{~cm}$ )

The 11 smear slides studied yielded diverse and well-preserved nannofossil assemblages (Fig. 4) that are assigned to the lower upper Paleocene. Reworking is present in all samples analyzed, particularly in the lowest one. All the reworked species identified belong to the Upper Cretaceous, commonly to the Maastrichtian.

The possible presence of a slump, which might have interlayered about $2.4 \mathrm{~m}$ of lower Paleocene sediments within a sequence of late Paleocene age, as previously reported by Storms, Natland, et al. (1991), is supported by the results of the biostratigraphic analysis. Indeed, in the two lowest and three highest samples of this interval (Fig. 4), we observed an association of Fasciculithus spp. that characterizes sediments not older than the lower part of Zone CP4. Moreover, these samples are almost devoid of Chiasmolithus danicus, a species that is rather abundant in the lower Paleocene but decreases gradually in abundance in the upper Paleocene. From Sample 132$810 \mathrm{C}-13 \mathrm{H}-4,69-71 \mathrm{~cm}$, to Sample $132-810 \mathrm{C}-13 \mathrm{H}-2,135-137 \mathrm{~cm}$, the assemblages are drastically different. Fasciculithus spp. is (almost) absent, whereas $C$. danicus is frequent to common. These assemblages are typical of the CP2-lower CP3 nannofossil zones.

\section{Early Eocene (Samples 132-810C-13H-2, 7-9 cm, to $132-810 \mathrm{C}-12 \mathrm{H}-2,120-122 \mathrm{~cm}$ )}

The 18 smear slides analyzed are assigned to the upper lower Eocene (Fig. 5). Preservation is moderate to good and reworking is rather abundant only in the two lowest samples of this interval. The age of the reworked taxa is mainly late Paleocene or Maastrichtian.

The entire Eocene interval probably belongs to Zone CP11. The species Discoaster sublodoensis, whose FO defines the base of Zone CP12, occurs within the oldest Neogene sediments overlying the hiatus. This finding allows us to infer that the hiatus between Paleogene and Neogene sediments occurred when Zone CP12 was just beginning.

\section{Middle Miocene-Pleistocene (Samples 132-810C-12H-2, $75-77 \mathrm{~cm}$, to $132-810 \mathrm{C}-1 \mathrm{H}-1,40-42 \mathrm{~cm}$ )}

The main part of the stratigraphic sequence drilled at Site 810 (i.e., approximately 100 out of $136 \mathrm{~m}$ ) belongs to this time interval. Neogene assemblages (Figs. 6 and 7) are characterized by variable preservation, although it is never poor. In particular, the middle Miocene associations are the worst, whereas nannofossils from the Pleistocene are the best preserved.

Besides the biostratigraphic scheme of Gartner (1977), we recognized at least one biostratigraphic event (the FO of large Gephyro- 


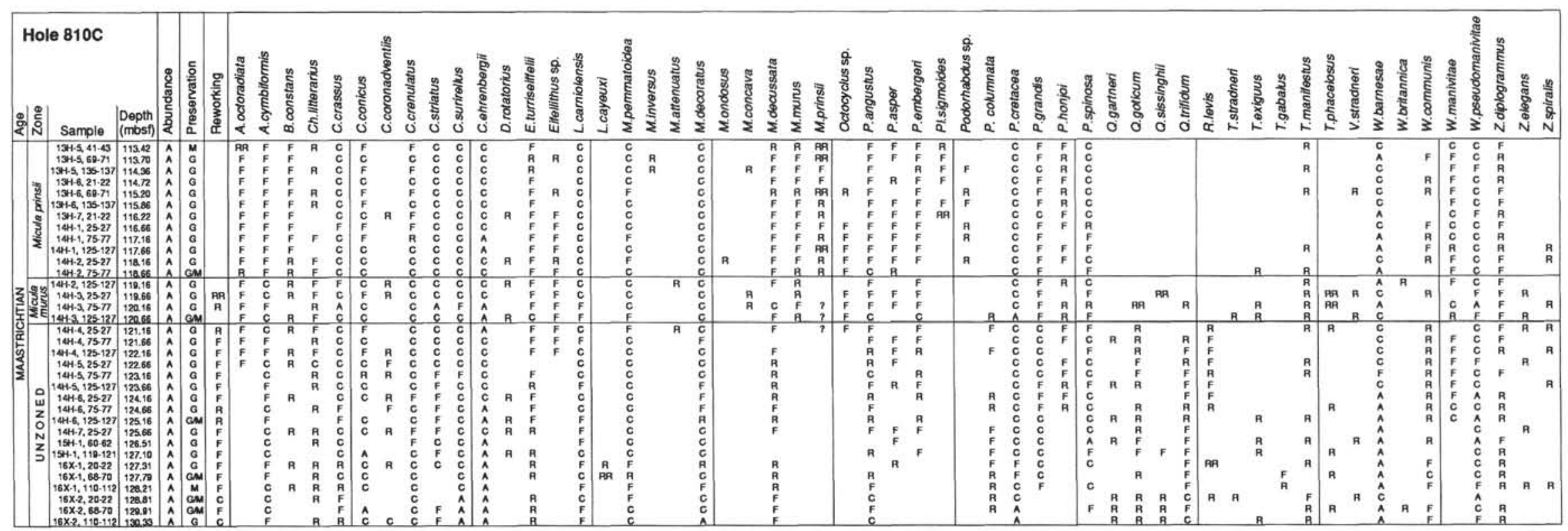

Figure 3. Distribution of calcareous nannofossils from Samples 132-810C-13H-5, 41-43 cm, to -16X-2, 110-112 cm (Maastrichtian). (For abundance abbreviations, see "Materials and Methods" section, this chapter.) 


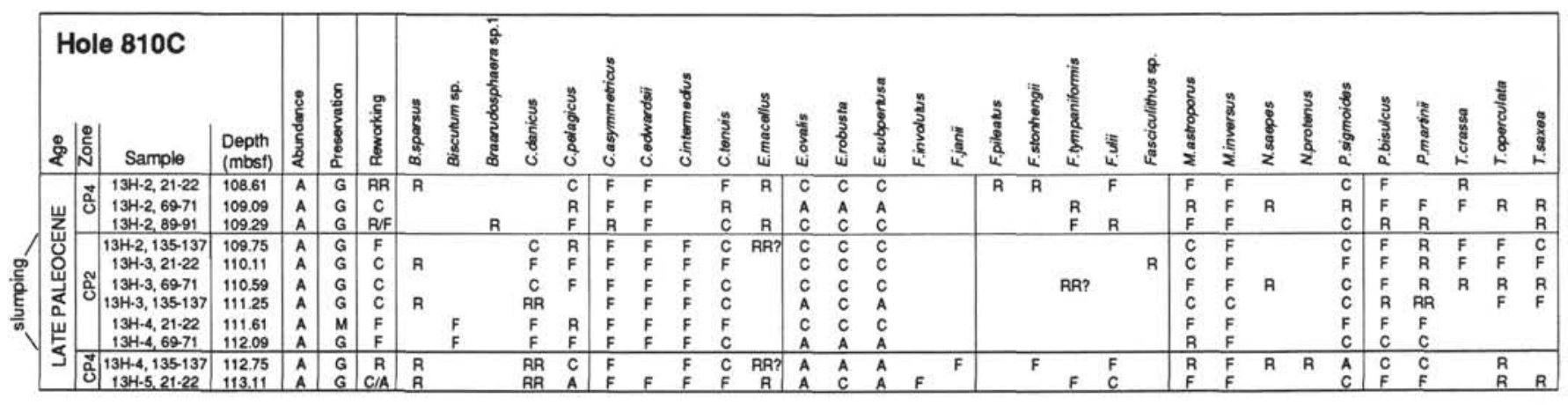

Figure 4. Distribution of calcareous nannofossils from Samples 132-810C-13H-2, 21-22 cm, to -13H-5, 2-22 cm (late Paleocene). (For abundance abbreviations, see "Materials and Methods" section, this chapter.)

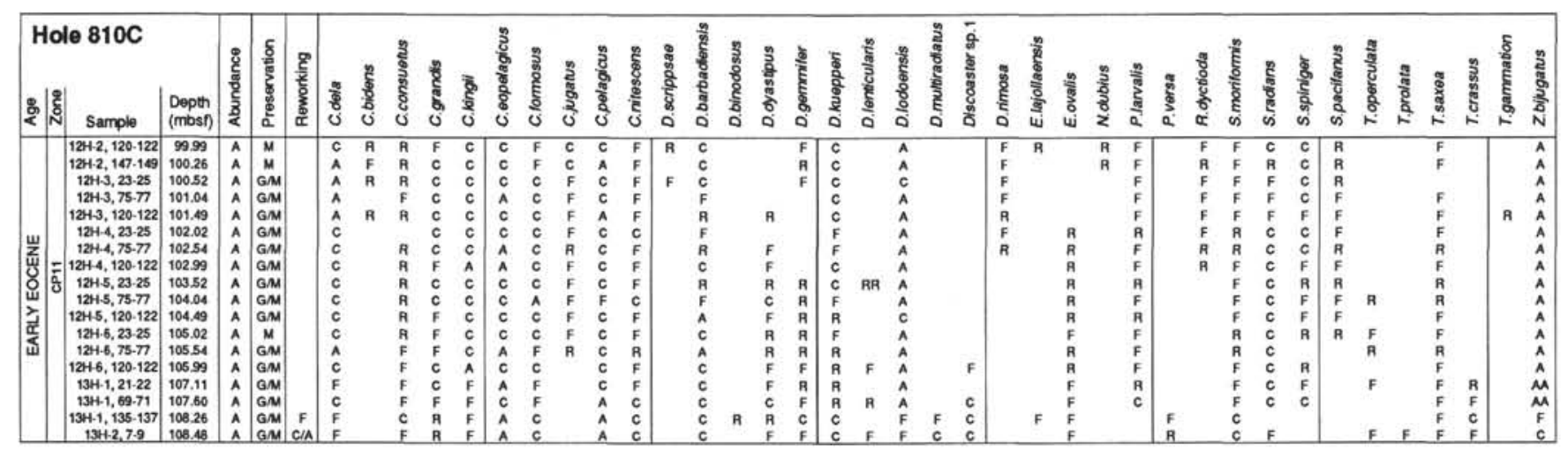

Figure 5. Distribution of calcareous nannofossils from Samples 132-810C-12H-2, 120-122 cm, to -13H-2, 7-9 cm (late early Eocene). (For abundance abbreviations, see "Materials and Methods" section, this chapter.)

capsa spp.; see Fig. 7) included in a nannofossil zonation recently proposed by Raffi and Rio (in Rio et al., 1990). This zonation refers directly only to the Mediterranean area; however, most of the biostratigraphic events included (among them the one mentioned above) are recognizable also in oceanic areas (Raffi et al., in press).

Sample 132-810C-12H-2, 75-77 cm, yielded the oldest Neogene species, tentatively attributable to Zone CN5, that were hardly identified among the very abundant Eocene taxa. The abundance of the reworked taxa is high in the lowest samples and decreases upward (Fig. 6).

Moving upward from the base of the Neogene sequence, we observed a hiatus near the middle/upper Miocene boundary where the whole Zone $\mathrm{CN} 7$, defined by the FO and last occurrence (LO) of Discoaster hamatus, and possibly part of Zones CN6 and CN8 are absent.

A minor hiatus was detected near the Pliocene/Pleistocene boundary, where the simultaneous disappearance of Discoaster brouweri and Calcidiscus macintyrei suggests that the Cyclococcolithina macintyrei (later referred to as Calcidiscus macintyrei) Subzone of Gartner (1977) is missing.

No sample attributable to the small Gephyrocapsa Zone has been observed during the analysis. Whether this is due to the low sampling resolution or to a hiatus is not clear (see below). The possible presence of this zone can be limited to the interval between Samples 132-810C$4 \mathrm{H}-5,110-112 \mathrm{~cm}$, and 132-810C-4H-2, 65-67 cm (Fig. 7).

The true first occurrence of Emiliania huxleyi, which was detected and dated at 268 k.y. on the basis of counts with a transmission electron microscope (Thierstein et al., 1977), may have been missed in this study as a result of the use of an optical microscope: the FO of this species as reported in Figure 7 can thus slightly postdate the real biostratigraphic event.
The uppermost sample analyzed, at $0.41 \mathrm{mbsf}$, did not reach the E. huxleyi Acme Zone, whose base has been dated by Thierstein et al. (1977) at 73 or 85 k.y., in transitional and subtropical/tropical waters, respectively.

\section{Planktonic Foraminifers}

Detailed study of planktonic and benthic foraminifer assemblages revealed that Cretaceous, Paleocene, Eocene, and upper Miocene sediments were commonly displaced, and assemblages were strongly affected by reworking. Nevertheless, range charts could be constructed for the Cretaceous and middle Miocene through middle Pleistocene sequence, whereas the strong mixing of the upper Paleocene and lower Eocene sediments, also associated with strong contamination, prevented us from establishing a clear stratigraphic distribution of the planktonic species (see below).

Generic attribution and identification of planktonic foraminifer zones follow Robazynski et al. (1984), Caron (1985), and Sliter (1989) for the Cretaceous; Boersma and Premoli Silva (1983), Toumarkine and Luterbacher (1985), Boersma et al. (1987), Premoli Silva and Boersma (1988), and Olsson et al. (1992) for the Paleocene and Eocene; and Blow (1969, 1979), Brönnimann and Resig (1971), and Kennett and Srinivasan (1983) for the Miocene through Pleistocene.

\section{Late Maastrichtian (Samples 132-810C-16X-CC to $132-810 \mathrm{C}-13 \mathrm{H}-5,41-43 \mathrm{~cm}$ )}

Planktonic foraminifer assemblages, studied in 39 samples from this interval, vary greatly in abundance from rich to poor. This distribution is well expressed in the weight percentage curve of Figure 8. 


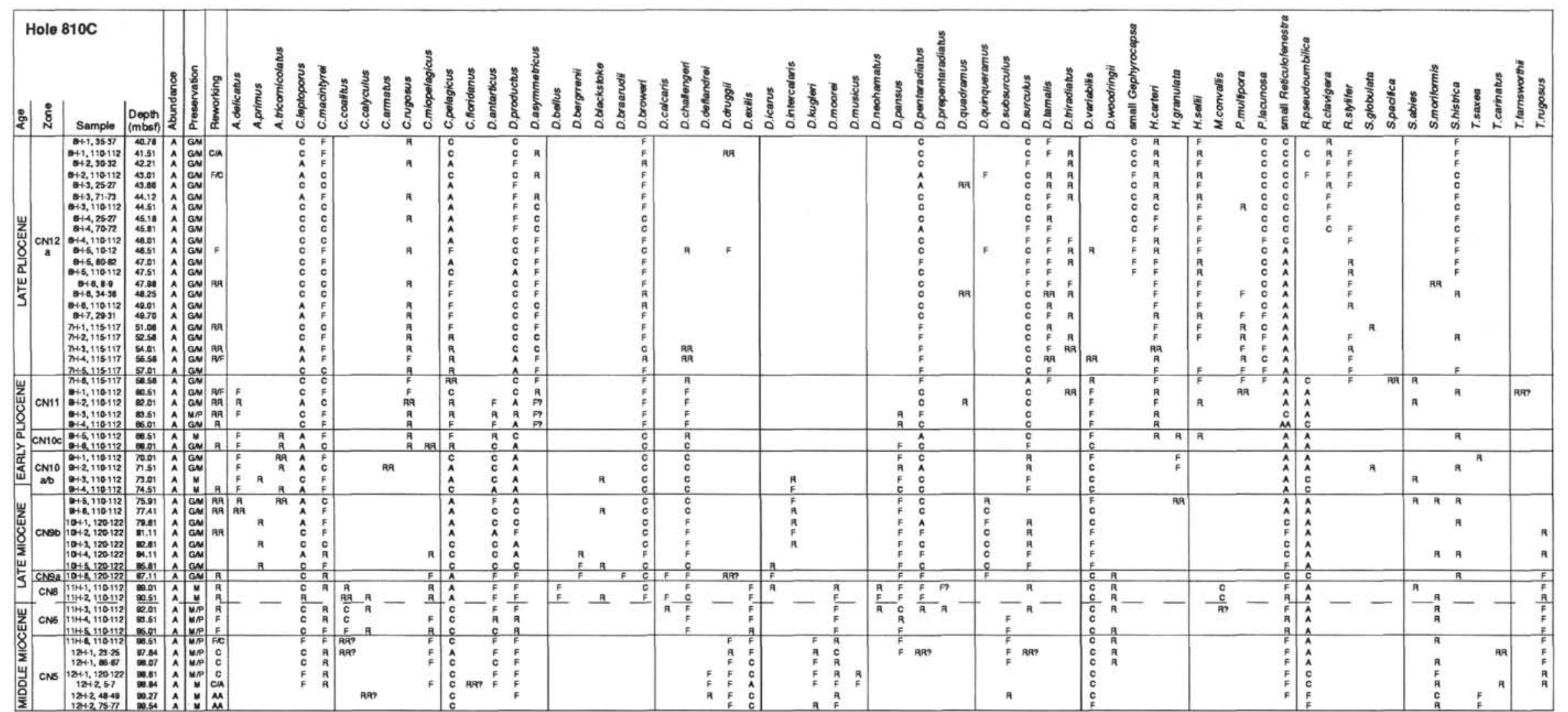

Figure 6. Distribution of calcareous nannofossils from Samples $132-810 \mathrm{C}-6 \mathrm{H}-1,35-37 \mathrm{~cm}$, to -12H-2, $75-77 \mathrm{~cm}$ (middle Miocene to late Pliocene). (For abundance abbreviations, see "Materials and Methods" section, this chapter.) 


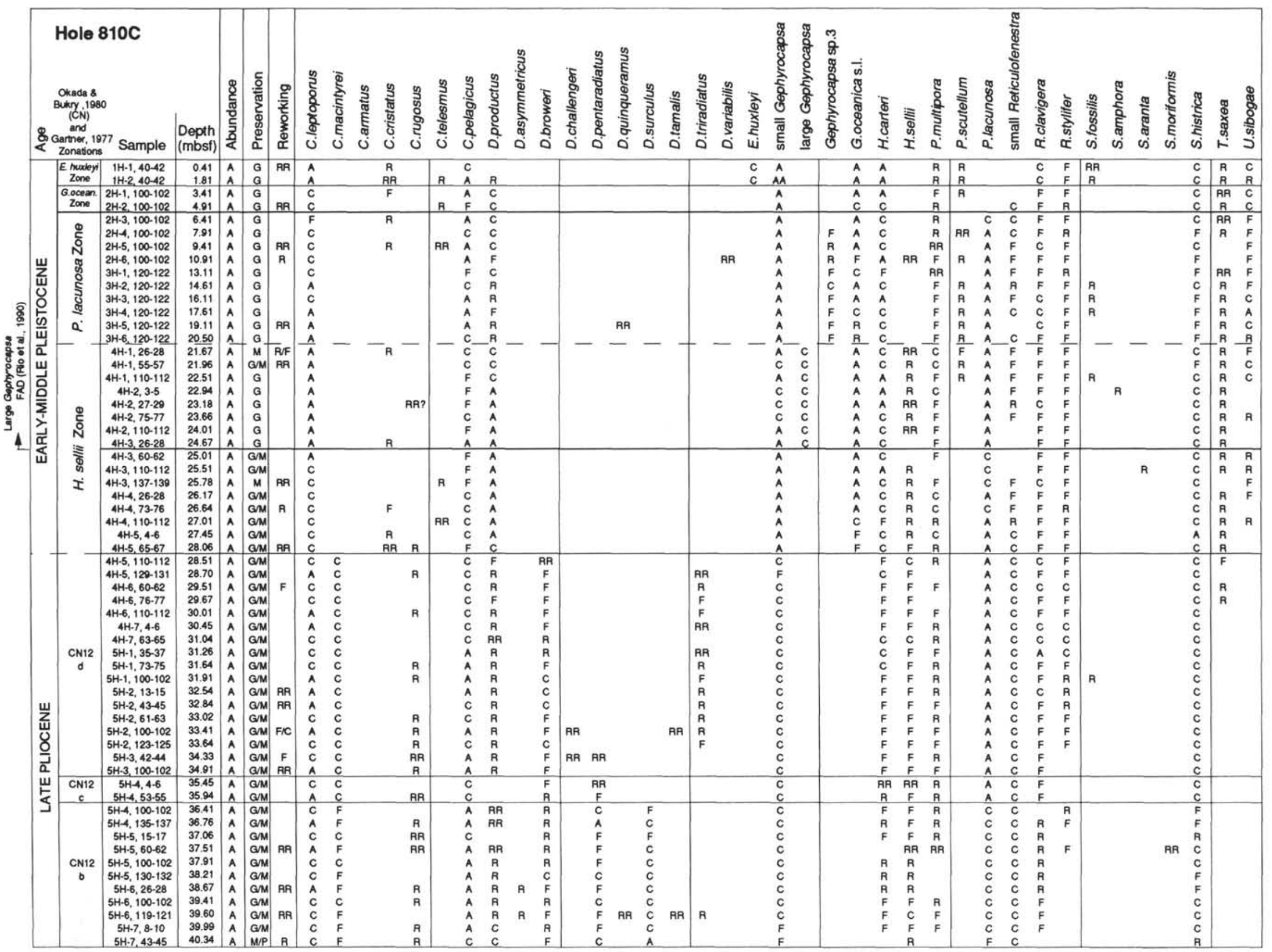




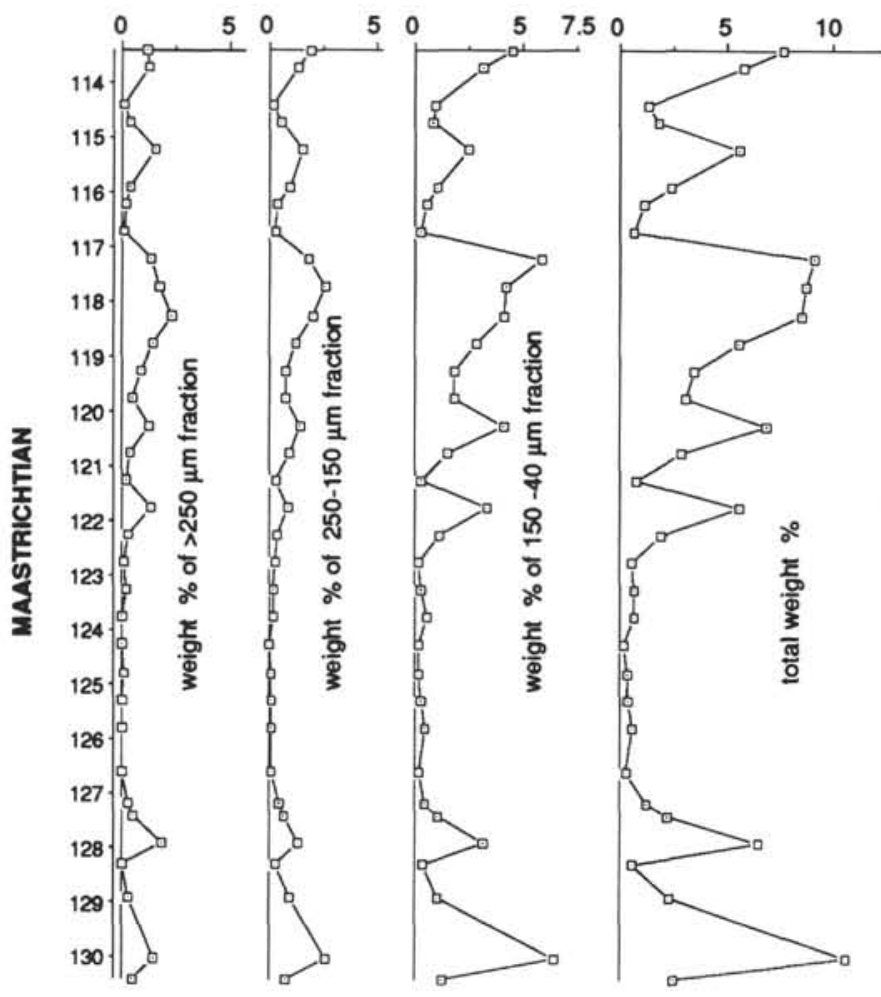

Figure 8. Total weight of washed residues and weight per $>250-, 250-150-$, and $150-40-\mu \mathrm{m}$ fractions expressed as percentage of the raw sample weight, from Samples 132-810C-13H-5, 41-43 cm, to - 16X-CC (Maastrichtian).

Low weight percentages correspond to very small residues in all the three fractions and especially in the $>250-\mu \mathrm{m}$ fraction (see also Fig. 9). High weight percentages correspond to samples yielding rich and well-diversified faunas, whereas the number of species is drastically reduced in samples with small residues. The preservation also varies from sample to sample and within a single sample from good or moderately good, to chalky and fragile, to recrystallized. The finest fractions $(150-40 \mu \mathrm{m})$ almost consistently contain a large amount of minute fragments. These differences in preservation occur in specimens belonging to the same species and in the same sample, suggesting that the assemblages result from mixing of in-situ and displaced faunas. The age difference of the variously preserved specimens is not so clearly detectable because the bulk of the assemblages comprises long-ranging taxa.

Despite such a bias, the stratigraphic distributions of taxa are plotted in the range chart of Figure 9. Also included are the overall planktonic foraminifer abundance, preservation, and dissolution, as well as the abundance of benthic foraminifers, other organisms, and inorganic components associated with the occurrence of reworking and contamination.

The oldest sample studied at the bottom of the hole (Sample $132-810 \mathrm{C}-16 \mathrm{X}-\mathrm{CC}$ ) yielded a few specimens attributable to Globotruncanella pschadae, an intermediate form between Globotruncanella havanensis and Abathomphalus intermedius, associated with Rugoglobigerina hexacamerata, $R$. reicheli, and Pseudoguembelina excolata. According to Caron (1985), all these species appear at the base of the Gansserina gansseri Zone (KS30 of Sliter, 1989) indicating that the oldest sediments at Hole $810 \mathrm{C}$ belong to the $G$. gansseri Zone of mid- to late Maastrichtian age. This attribution is corroborated by the successive appearances of Globotruncanita pettersi (Sample 132810C-16X-2, 68-70 cm), Abathomphalus intermedius (Sample 132$810 \mathrm{C}-15 \mathrm{H}-1,119-121 \mathrm{~cm}$ ), Planoglobulina multicamerata (Sample 132-810C-14H-7, 25-27 cm), Planoglobulina acervulinoides (Sam- ple 132-810C-14H-6, 125-127 cm), Contusotruncana walfischensis (Sample 132-810C-14H-5, 75-77 cm), and Trinitella scotti (Sample $132-810 \mathrm{C}-14 \mathrm{H}-4,25-27 \mathrm{~cm}$ ). According to Caron (1985), the occurrence of all these species indicates that the succession is progressing from the middle to the upper part of the $G$. gansseri Zone.

The occurrence of primitive specimens of Abathomphalus mayaroensis in Sample 132-810C-14H-2, 125-127 cm, marks the beginning of the nominal zone (KS31 of Sliter, 1989), the youngest zone of the Cretaceous. Therefore, the Maastrichtian sediments at the bottom of Hole $810 \mathrm{C}$ are younger than previously thought (attributed to the Globotruncanella havanensis and Globotruncana aegyptiaca Zones of the early Maastrichtian in Storms, Natland, et al., 1991).

It is worth mentioning that (1) G. gansseri, true Contusotruncana contusa, and Rugoglobigerina rotundata were never observed in Hole $810 \mathrm{C} ;(2)$ the assemblages are dominated by double keeled globotruncanids, which should decrease in abundance throughout the upper part of the Maastrichtian (Premoli Silva and Boersma, 1977); and (3) the lowermost core, Core $132-810 \mathrm{C}-16 \mathrm{X}$, which was highly disturbed by drilling, yielded in several samples some specimens attributable to Globotruncanita atlantica, Ventilabrella eggeri, and very rare Globotruncanita elevata, which all should have become extinct at the end of the Campanian.

Whereas the absence of the species mentioned at point (1) is not easy to understand, the other two features mentioned in (2) and (3) may be easily explained by displacement and reworking. Displacement and reworking are also demonstrated by the benthic foraminifers associated with the planktonic assemblages. Although the anomalously high abundance of benthic foraminifers indicates that the planktonic foraminifers were affected by strong dissolution, as in several samples belonging to Cores $132-810 \mathrm{C}-14 \mathrm{H}$ and $-15 \mathrm{H}$, the benthic faunas, even in these cases, included genera such as Stensioina, ornamented Lenticulina, Marssonella, and numerous buliminids among others, whose habitat is not consistent with the $>2600$ - $\mathrm{m}$ water depth of Site 810 ; on the contrary, they indicate an upper bathyal environment. Also, the lower bathyal indicator and most consistent genus, Aragonia, displays a variety of preservation from well-preserved, almost transparent specimens to broken and worn ones in the same sample.

\section{Late Paleocene (Samples 132-810C-13H-5, 35-36 cm, to $132-810 \mathrm{C}-13 \mathrm{H}-2,21-22 \mathrm{~cm}$ )}

A very slight difference in color in Section 132-810C-13H-5, 40 $\mathrm{cm}$, corresponds to a major hiatus that removed the uppermost part of the A. mayaroensis Zone and the entire lower Paleocene. In fact, the presence of Morozovella angulata and Globanomalina ehrenbergi in the lowermost sample of this interval indicates Zone P3b, or less likely the topmost part of Zone P3a, of late Paleocene age. This attribution is confirmed by the occurrence of Morozovella pusilla, the index species of Zone P3b, in Sample 132-810C-13H-5, 20-22 cm.

Planktonic foraminifer assemblages in this interval are rich in species with an usually excellent preservation of at least the largesized forms. However, the assemblages are strongly mixed either by contamination or by heavy reworking. Contaminants even include species from the Pleistocene, although they are most commonly from the lower Eocene. Reworking involved planktonic species from Zone Palpha, the entire Zone P1, and Zone P2, which occur either mixed together or preferentially from a single zone. The most common reworked species are Praemurica trinidadensis, Praemurica uncinata, Praemurica praecursoria, Globoconusa daubjergensis, and the woodringinids, guembelitrids, and sometimes Parvarugoglobigerina eugubina. Few globotruncanids may also occasionally occur.

In the interval from Sample $132-810 \mathrm{C}-13 \mathrm{H}-4,99-100 \mathrm{~cm}$, to $-13 \mathrm{H}-2,69-71 \mathrm{~cm}$, the assemblages are predominantly constituted by forms from Zones Palpha and P1 with the species from Zone P3b almost absent. The preliminary interpretation (Storms, Natland, et al., 1991), supported by the different and variable dip recorded in these strata, was that this portion was slumped within sediments of Zone 


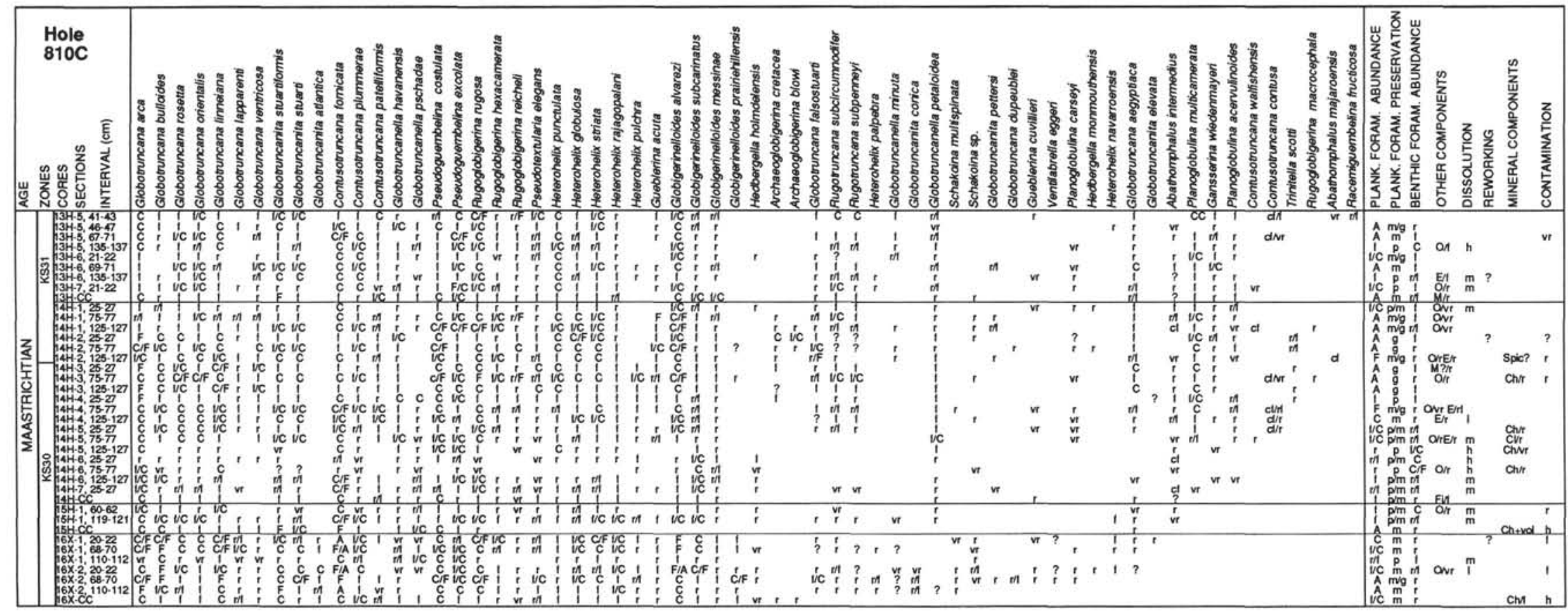

Figure 9. Distribution of planktonic foraminifers from Samples $132-810 \mathrm{C}-13 \mathrm{H}-5,4 \mathrm{I}-43 \mathrm{~cm}$, to $-16 \mathrm{X}-\mathrm{CC}$ (Maastrichtian). Abundance; $\mathrm{vr}=\mathrm{very}$ rare; $\mathrm{r}=\mathrm{rare} ; \mathrm{f}=\mathrm{few} ; \mathrm{C}=\mathrm{common} ; \mathrm{F}=\mathrm{frequent} ; \mathrm{A}=\mathrm{abundant}$ Dissolution: $\mathrm{I}=$ low; $\mathrm{m}=$ medium; $\mathrm{h}=$ high. Other organisms: $\mathrm{O}=$ ostracodes; $\mathrm{E}=$ echinoderms; $\mathrm{M}=$ mollusks; $\mathrm{Fi}=\mathrm{fish}$ remains; Spic $=$ sponge spicules. Mineral components: ch $=$ chert; vol = volcanics. For key to other symbols, see text. 
P3b. This interpretation still holds except that most samples also yielded some rare forms from the enveloping Zone P3b (the assemblages are again a mixture). Because of these disturbances no routine range chart could be produced for this interval. Instead, the major biostratigraphic events are plotted against lithology and depth in a closeup of Core 132-810C-13H in Figure 10, with a few remarks on the occurrence of the reworked material. These sedimentary features are well expressed in the weight percentage curves of Figure 11 (note the large fluctuations in the total weight percentage curve). Total weight percentages are overall much higher than in the Maastrichtian portion. The very low weight percentages in the $>250-\mu \mathrm{m}$ fraction curve reflect that the reworked faunas are composed of small-sized forms such as those from the older zones of the Paleocene. The highest weight percentages correspond to samples yielding very rich and well-diversified faunas.

The planktonic assemblages, supposed to be autochthonous, are typically tropical and include numerous Morozovella angulata, $M$. abundocamerata, $M$. conicotruncata, $M$. aequa, Muricoglobigerina mckannai, Parasubbotina pseudobulloides, P. varianta, Subbotina triloculinoides, Globanomalina ehrenbergi, G. compressa, and rare acarininids.

The benthic foraminifer assemblages throughout the interval vary in abundance from almost absent to common. In the latter case the assemblages display a highly mixed nature with lower bathyal forms such as Aragonia, Pleurostomella, thin Dentalina, and Nuttallides, among others, associated with upper to middle bathyal forms, including numerous buliminids and bolivinids and large-sized Lenticulina. Specimens of Aragonia display different preservation in some samples as mentioned in the previous interval. A few very altered glauconite grains are scattered throughout.

\section{Early Eocene (Samples 132-810C-13H-2, 7-9 cm, to 132-810C-12H-2, 75-77 cm)}

A slight difference in color without any apparent change in the composition of the ooze marks the second major hiatus in Section 132-810C-13H-2 between the upper Paleocene and lower Eocene sediments. This interval is topped by a very soupy interval from 50 to $57 \mathrm{~cm}$ in Section 132-810C-12H-2, above which the sediments are attributable to the middle Miocene (Fig. 10).

The planktonic foraminifer assemblages from this interval are more monotonous than in the previous intervals with the bulk of faunas consistently constituted by forms belonging to Zones P6b, P8, and $\mathrm{P} 9$. The Zone P9 assemblage is apparently diluted into Zone P8 faunas. The total weight percentage and the three weight fraction curves reflect this homogeneity (Fig. 11) with the exception of the lowermost two samples. The latter, corresponding to highest weight percentages that are highly visible also in the $>250-\mu \mathrm{m}$ fraction curve, yielded more abundant reworked faunas also attributable to Zone P5 of late Paleocene age (missing below).

Zonal attribution is based on the occurrence of few specimens of Turborotalia frontosa and forms close to Truncorotaloides topilensis in Sample 132-810C-13H-2, 7-9 cm. This attribution is corroborated by the occurrence of "Globigerinatheka" senni, Pseudohastigerina danvillensis, and very rare Globigerinatheka micra in the absence of hantkeninids and Pseudohastigerina micra. The most common forms throughout are Morozovella aragonensis, $M$. caucasica, $M$. crassata, Acarinina bullbrooki, A. rotundimarginata, A. rugosoaculeata, and A. pseudotopilensis. Less frequent but consistently present are " $G$." senni, Guembelitrioides higginsi, Globanomalina pseudoscitula, A. rohri, and rarer Acarinina pentacamerata.

The preservation is variable within a single sample, with the same species such as $M$. aragonensis and $M$. caucasica represented by fragile, worn individuals associated with recrystallized specimens; nicely preserved specimens are rarely present. This suggests that part of the faunas are resedimented and possibly also reworked. Benthic foraminifers are also mixed from different bathymetric zones (upper to lower bathyal) as in the previous intervals, although they are overall much less frequent.

\section{Middle Miocene to Pleistocene}

Considerable difficulty was encountered in applying the existing zonation to the Hole $810 \mathrm{C}$ planktonic foraminifer assemblages, because strong dissolution episodes that occur throughout the middle Miocene to most of the Pliocene sedimentary section also removed some of the dissolution-resistant markers (e.g., Sphaeroidinella dehiscens). This is well expressed in the weight percentage curves, especially in that of the $>250-\mu \mathrm{m}$ fraction, and by the overall scarcity of the residues from the lower two-thirds of the Neogene sequence (Figs. 12 and 13). Moreover, the distribution of some species used as markers is apparently strongly controlled by environmental conditions.

The strong reworking and/or dissolution episodes affecting a large part of the sedimentary sequence prevented a reliable reconstruction of the succession of bioevents. In such conditions, we could rely only on the first evolutionary occurrence of taxa for biostratigraphic assignment and had to disregard extinction events and assemblage characteristics.

Nevertheless, the standard zonal scheme of Blow (1969) is tentatively applied to the Neogene tropical assemblages of Hole 810C. The distribution of the identified planktonic foraminifer species and groups are reported in the range chart of Figure 13. The major events used for identifying the zonal boundaries or zones are listed below (from old to young):

1. The co-occurrence of abundant Zeaglobigerina nepenthes and Z. microstoma, equated to Zone N14-N15 (middle to upper Miocene).

2. The FO of Globorotalia merotumida followed $1.5 \mathrm{~m}$ above by the FO of Neogloboquadrina pachyderma identifies Zone N16 (upper Miocene).

3. The co-occurrence of Globorotalia plesiotumida and Globigerinoides extremus identifies Zone $\mathrm{N} 17$ (upper Miocene).

4. The FO of Globorotalia margaritae primitiva and the LO of Globorotalia merotumida identify the upper Zone N17 (upper Miocene).

5. The FO of Globorotalia tumida s.s. equates to the base of Zone N18 (lower Pliocene).

6. The FO of Globorotalia margaritae margaritae, followed 1.5 $\mathrm{m}$ above by the FO of $G$. margaritae evoluta and Zeaglobigerina incisa, $5 \mathrm{~m}$ above by the FO of Globorotalia crassaformis, and $6 \mathrm{~m}$ above by the FO of Sphaeroidinella dehiscens and Globorotalia puncticulata identifies Zones N18 to N20 (lower Pliocene).

7. The LO of Globigerinoides extremus, followed about $1 \mathrm{~m}$ above by the LO of G. puncticulata, and $2 \mathrm{~m}$ above by the FO of Globorotalia crassaformis viola identifies the upper Zone N21 (upper Pliocene).

8. The FO of Truncorotalia truncatulinoides equates to the base of Zone N22 (uppermost Pliocene).

9. The FO of Globigerina calida equates to the base of Zone N23 (lower Pleistocene).

\section{Middle to late Miocene (Samples 132-810C-12H-2, 75-77 cm, to $132-810 \mathrm{C}-9 \mathrm{H}-5,110-112 \mathrm{~cm}$ )}

This interval is characterized by highly dissolved and scarce middle to upper Miocene planktonic foraminifer faunas and by common to abundant, mainly fragmented Cretaceous (Heterohelix striata, Globotruncana spp.) to Paleocene and Eocene (Praemurica uncinata, Morozovella gracilis, Parasubbotina pseudobulloides, Morozovella caucasica, etc.) reworked faunas. Therefore, no zonal assignment can be made with certainty. The high-dissolution episode is also corroborated by abundant benthonic foraminiferal faunas and by rare to very abundant crystals and/or fragments of clinoptilolite (see Fig. 13).

The oldest Miocene sample (132-810C-12H-2, 75-77 cm) examined is tentatively referred to Zone $\mathrm{N} 14-\mathrm{N} 15$ based on the occurrence 


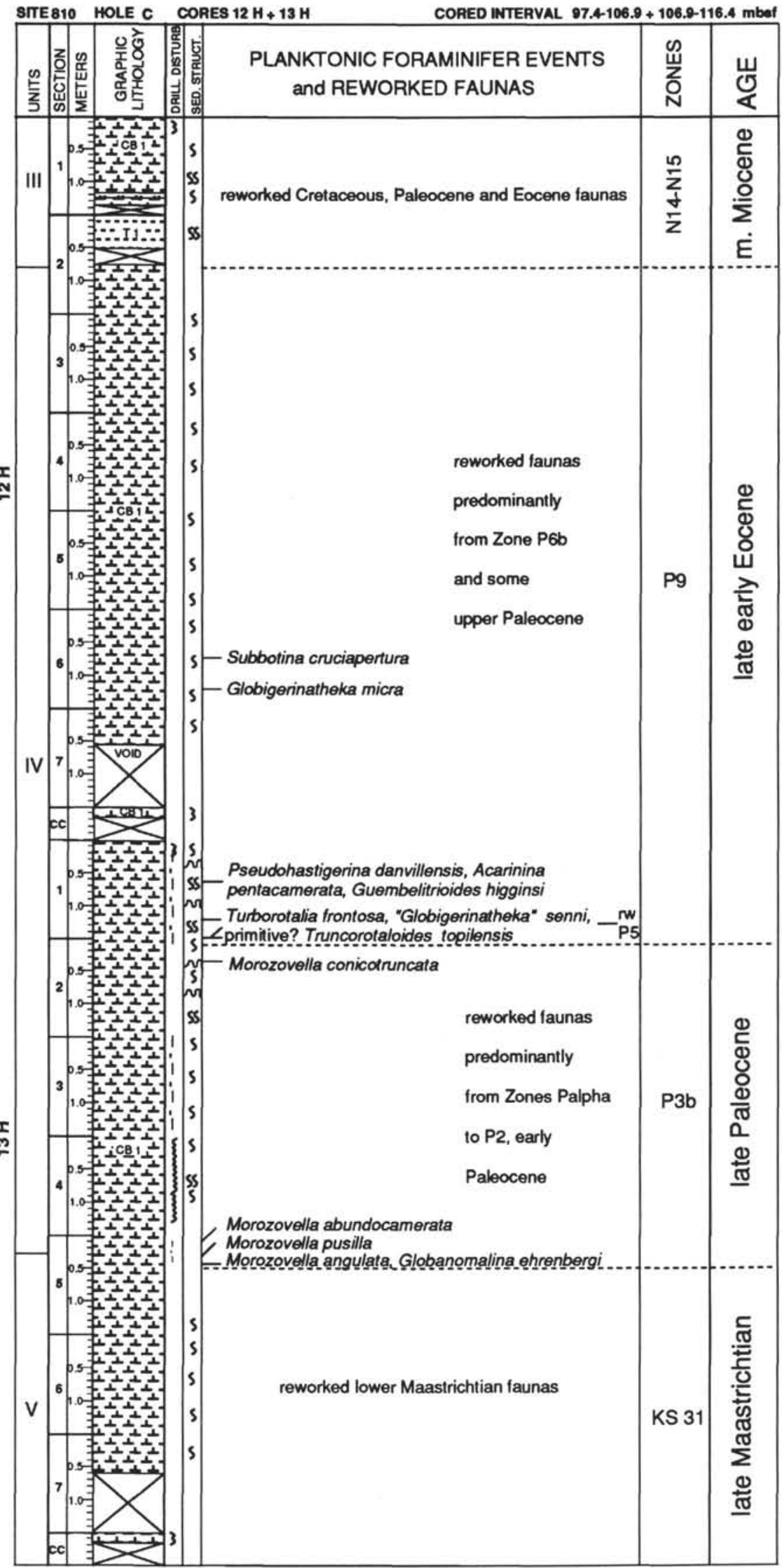

Figure 10. Close-up of Cores $132-810 \mathrm{C}-12 \mathrm{H}$ and $-13 \mathrm{H}$ with lithology, major planktonic foraminifer events, and sedimentary characteristics (late Maastrichtian to late early Eocene). 


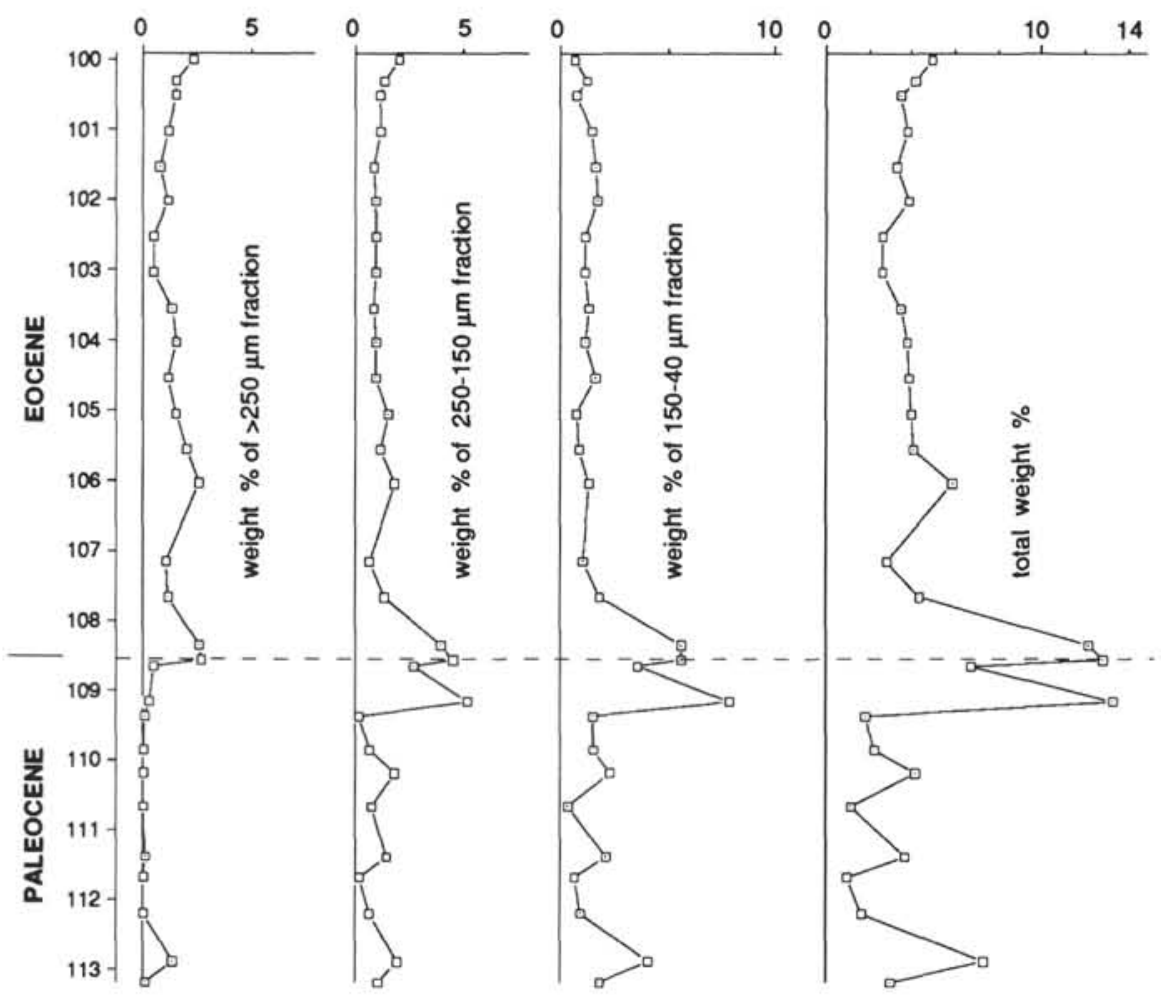

Figure 11. Total weight of washed residues and weight per $>250-, 250-150-$, and $150-40 \mu \mathrm{m}$ fractions expressed as percentage of the raw sample weight from Samples 132-810C-12H-2, 120-122 cm, to $-13 \mathrm{H}-5,21-22 \mathrm{~cm}$ (late early Eocene to late Paleocene).

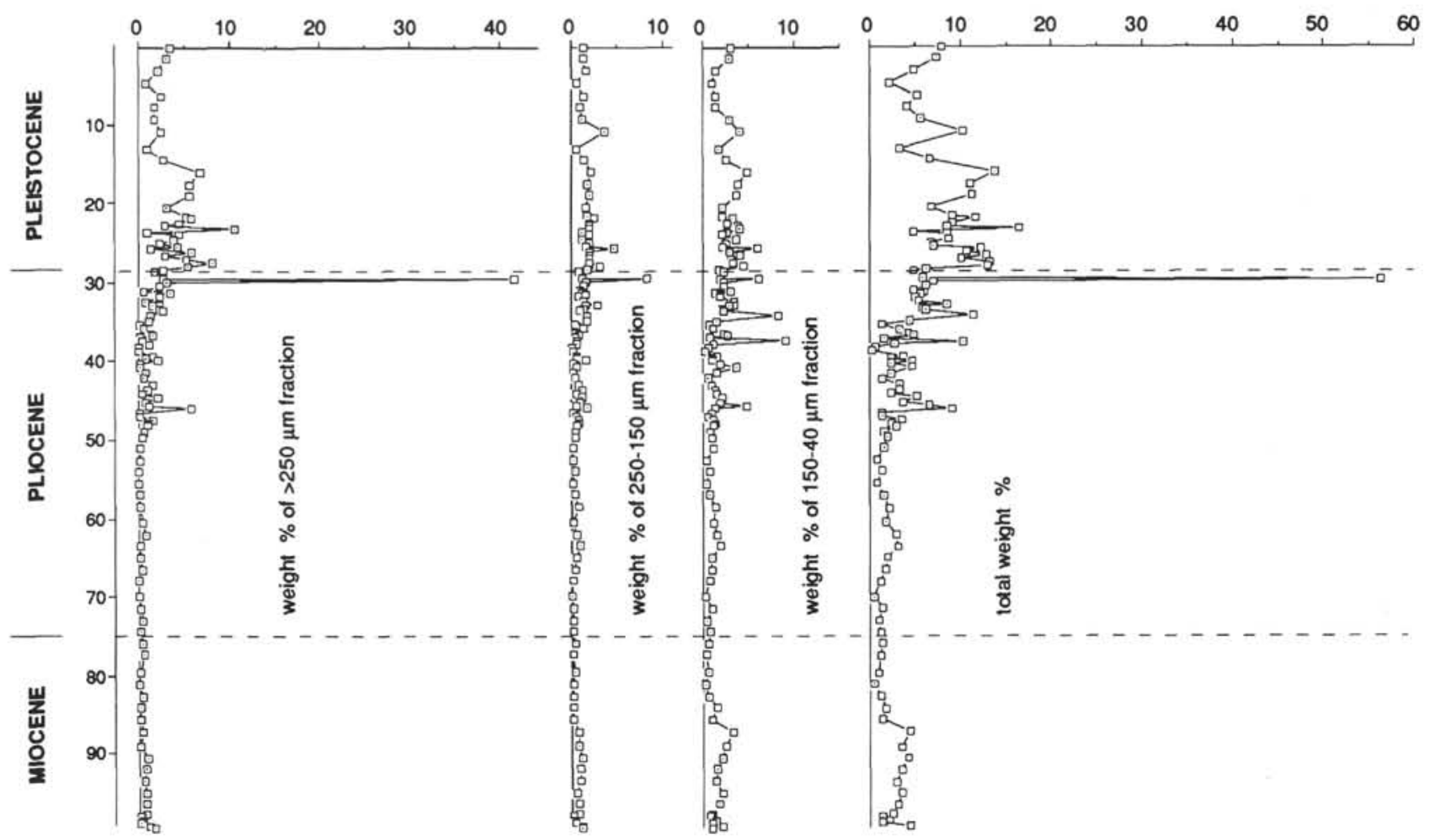

Figure 12. Total weight of washed residues and weight per $>250-, 250-150-$, and $150-40-\mu \mathrm{m}$ fractions expressed as percentage of the raw sample weight from Samples $132-810 \mathrm{C}-1 \mathrm{H}-1,40-42 \mathrm{~cm}$, to $-12 \mathrm{H}-1,120-122 \mathrm{~cm}$ (middle Miocene to Pleistocene). 


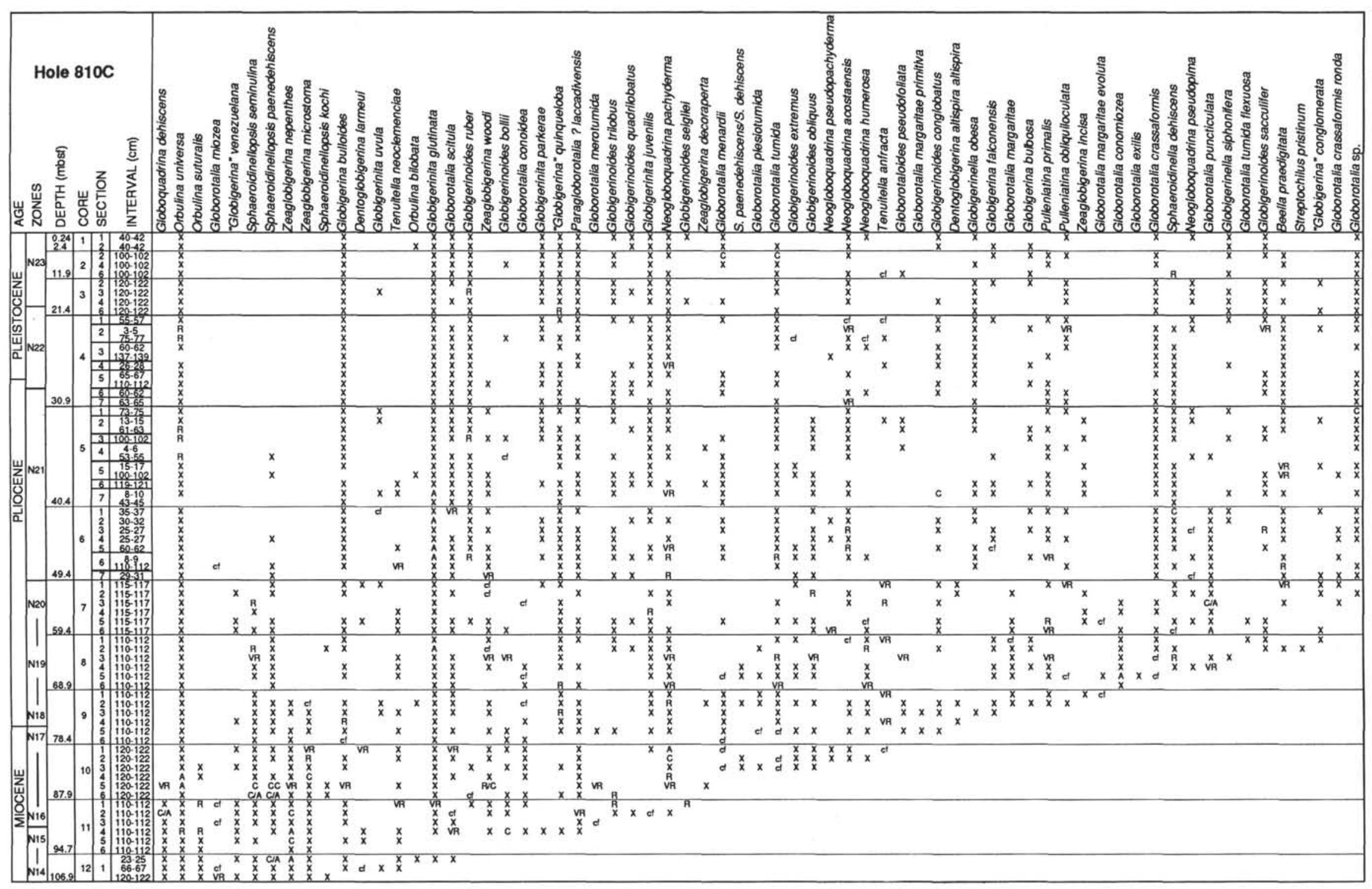

Figure 13. Distribution of planktonic foraminifers from Samples 132-810C-1H-1, 40-42 cm, to -12H-1, 120-122 cm (middle Miocene through middle Pleistocene). 


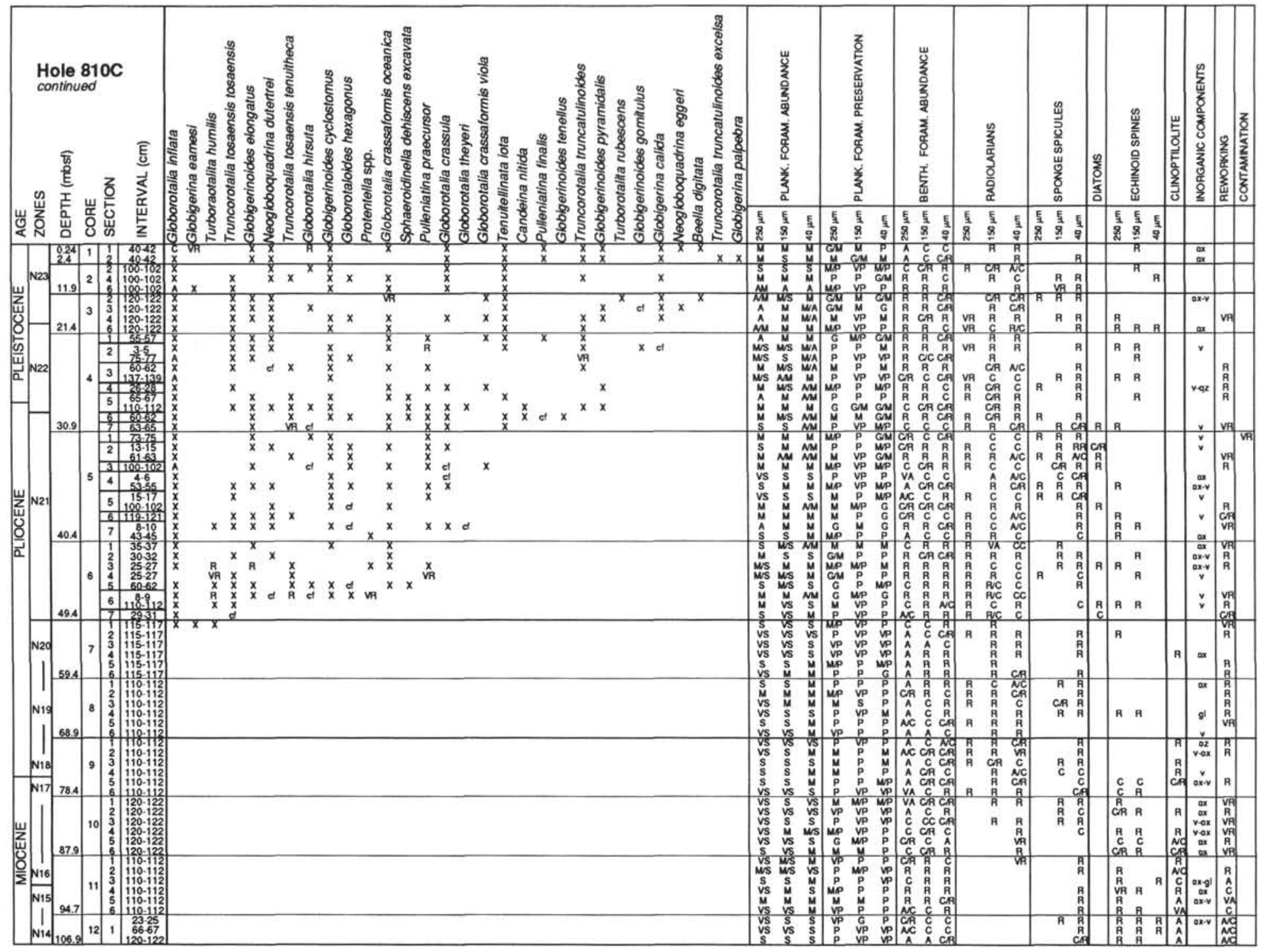

Figure 13 (continued). 
of abundant to dominant Zeaglobigerina nepenthes and Zeoglobigerina microstoma in the absence of youngest forms. The N14/N15 zonal boundary, placed by Blow (1969) upon the last occurrence of Paragloborotalia siakensis, was not identified because this species is absent in the studied samples.

The boundary between the N14-N15 and N16-N17 zonal intervals is here placed with the FO of Globorotalia merotumida, although this species is generally very rare in the Hole $810 \mathrm{C}$ assemblages. The FO of Neogloboquadrina acostaensis, suggested by Blow (1969) to mark the N15/N16 zonal boundary, is not here used because the appearance of this species is older (D. Rio, pers. comm., 1992).

The N16-N17 zonal interval assemblages consist of common Zeaglobigerina nepenthes and Z. microstoma, Orbulina spp., and Sphaeroidinellopsis spp. In the upper part of this interval the rare specimens of $G$. merotumida are associated with rare specimens of $G$. plesiotumida and $G$. cf. tumida.

\section{Pliocene (Samples 132-810C-9H-4, 110-112 cm, to $132-810 \mathrm{C}-4 \mathrm{H}-5,110-112 \mathrm{~cm})$}

The preservation and abundance of the planktonic foraminifer faunas vary from sample to sample and increase upward from very scarce to abundant and from very poor to good, respectively. Benthic foraminifer faunas are generally common and abundant, whereas the reworked faunas (Cretaceous to Eocene) are less abundant than in the previous interval. Radiolarians increase in abundance upward and diatoms are present only in Cores $132-810 \mathrm{C}-6 \mathrm{H}$ and $-5 \mathrm{H}$ (Zone N21) (Fig. 13).

The Miocene/Pliocene boundary is placed by Blow (1969) within Zone N18. According to nannofossil and paleomagnetic data from Hole $810 \mathrm{C}$ (see above), this boundary, here placed between Samples $132-810 \mathrm{C}-9 \mathrm{H}-5,110-112 \mathrm{~cm}$, and $132-810 \mathrm{C}-9 \mathrm{H}-4,110-112 \mathrm{~cm}$, corresponds to the base of Zone N18 as marked by the FO of Globorotalia tumida. This definition of Zone N18 was already proposed by Berggren (1973), Fleisher (1974), and Vincent (1975), the latter at Site 305, which is also drilled on the Shatsky Rise.

The N18/N19 zonal boundary is not distinguished here as defined by Blow (1969) because of persistent dissolution that removed the marker species, Sphaeroidinella dehiscens. Moreover, the FO of Neogloboquadrina pseudopima could not be used to place the N19/N20 boundary, because this taxon is reported from the upper Zone N18 (Brönnimann and Resig, 1971; Fleisher, 1974).

According to Brönnimann and Resig (1971) and Berggren (1973), the LO of Globorotalia margaritae should identify the N19/N20 zonal boundary, whereas the base of Zone N21 is equated to the FO of the Globorotalia tosaensis group. The latter event occurs less than $3 \mathrm{~m}$ above the disappearance of $G$. margaritae, which results in a very thin Zone N20 at Site 810. Zone N20 was not identified at Site 305 (Vincent, 1975).

The assemblage of Zone N21 is dominated by representatives of the Globorotalia crassaformis group associated with rare Neogloboquadrina dutertrei, Globigerinoides spp., Pulleniatina praecursor, and very few specimens of Globorotaloides hexagonus and Globorotalia theyeri. The N21/N22 zonal boundary is equated to the FO of Truncorotalia truncatulinoides, a latest Pliocene event.

\section{Pleistocene (Sample 132-810C-4H-5, 65-67 cm, upward)}

Both the abundance and preservation of the planktonic foraminifer assemblages improve slightly in this interval, whereas benthic foraminifers decrease in abundance. Resedimented specimens are rare. Although fragmentation varies among samples from moderate to high, we could determine that the Pleistocene faunas are typical of tropical assemblages of this age.

According to nannofossil and paleomagnetic data, the Pliocene/Pleistocene boundary falls within the lower part of Zone N22, just above the FO of $T$. truncatulinoides, in accordance to the record from the Mediterranean (Rio et al., 1984, 1991). T. truncatulinoides is consistently present but relatively rare and occurs associated with N. dutertrei, common Globigerinoides ruber, Globorotalia tumida, and representatives of the $G$. crassaformis group.

The N22/N23 zonal boundary is tentatively placed with the FO of Globigerina calida, although according to Brönnimann and Resig (1971) this species in the southwestern Pacific predates the FO of $T$. truncatulinoides.

\section{INTERPRETATION OF MAGNETOSTRATIGRAPHY AT HOLE 810C}

The calcareous nannofossil biostratigraphy of the Neogene portion recovered in Hole $810 \mathrm{C}$ allows us to correctly interpret the magnetic stratigraphy published in the Initial Reports volume for Leg 132 (Storms, Natland, et al., 1991, p. 88-92), in which it was stated that "the magnetic polarity reversals are identified as normal polarity for negative values of inclination and reversed polarity for positive values of inclination." This unusual interpretation of the magnetic signal was the result of the cryogenic magnetometer being miswired during Leg 132 (see Sager et al., this volume). Accordingly, the calcareous nannofossil biostratigraphy, reconstructed here, indicates that the interval from 0 to about $18.1 \mathrm{mbsf}$ in figure 15 (Storms, Natland, et al., 1991) must be ascribed to the Brunhes Chron (Figs. 14 and 15) (see Sager et al., this volume).

At 20.7-21.6, 28.4-28.6, and 31.1-31.3 mbsf, three short positive events occurring in the underlying Matuyama Chron can be identified as the Jaramillo, Olduvai, and Réunion Events, respectively. The relatively thin Jaramillo Event and the identification near its base of the H. sellii Zone of Gartner (1977), instead of the small Gephyrocapsa Zone, led us to infer the presence of a short hiatus involving the lower part of this magnetic event (see also above).

We have already pointed out that the biostratigraphy suggests the presence of a hiatus across the Pliocene/Pleistocene boundary, based on the simultaneous extinction of $D$. brouweri and $C$. macintyrei. This would justify the very low thickness of the Olduvai Event, which is probably truncated at its top.

The underlying Gauss and Gilbert Chrons seem to be fully represented in the stratigraphic sequence: the Kaena and Mammoth (negative events within the Gauss), Cochiti, Nunivak, Sidutjall, and Thvera (positive events within the Gilbert) are indeed nicely expressed (Figs. 14 and 15). The calcareous nannofossil data are always in good to excellent agreement with the reinterpreted magnetic stratigraphy.

Below the lower boundary of the Gilbert Chron (i.e., below 75 mbsf) the reversal pattern is more complicated. Moreover, the presence of at least one hiatus and the relatively low number of samples analyzed prevent us from reaching a final interpretation. The same holds true for the Eocene, Paleocene, and Maastrichtian intervals.

On the basis of the reversal ages published in the literature, we estimated the accumulation rate curve (Fig. 14). In Figure 14, two alternative curves are shown, following different dating methods: the first one is based on seafloor anomalies (Harland et al., 1989), the second one on astronomical calibrations (Shackleton et al., 1990; Hilgen, 1991a, 1991b). In the same figure, the depth position of the bioevents is also reported on the right side and can be projected on the two accumulation curves. This allows us to infer the relative position of the bioevents with respect to magnetic reversals and the resulting biochronologies.

\section{SUMMARY AND CONCLUSIONS}

The biostratigraphic analysis of the calcareous oozes recovered in Hole $810 \mathrm{C}$ revealed that the $136 \mathrm{~m}$ of sediments span an interval from upper Maastrichtian to upper Pleistocene. Biostratigraphic data are based on both calcareous nannofossils and planktonic foraminifers and resulted in consistent correlation throughout, although the calcareous nannofossils provided a better resolution especially in the 


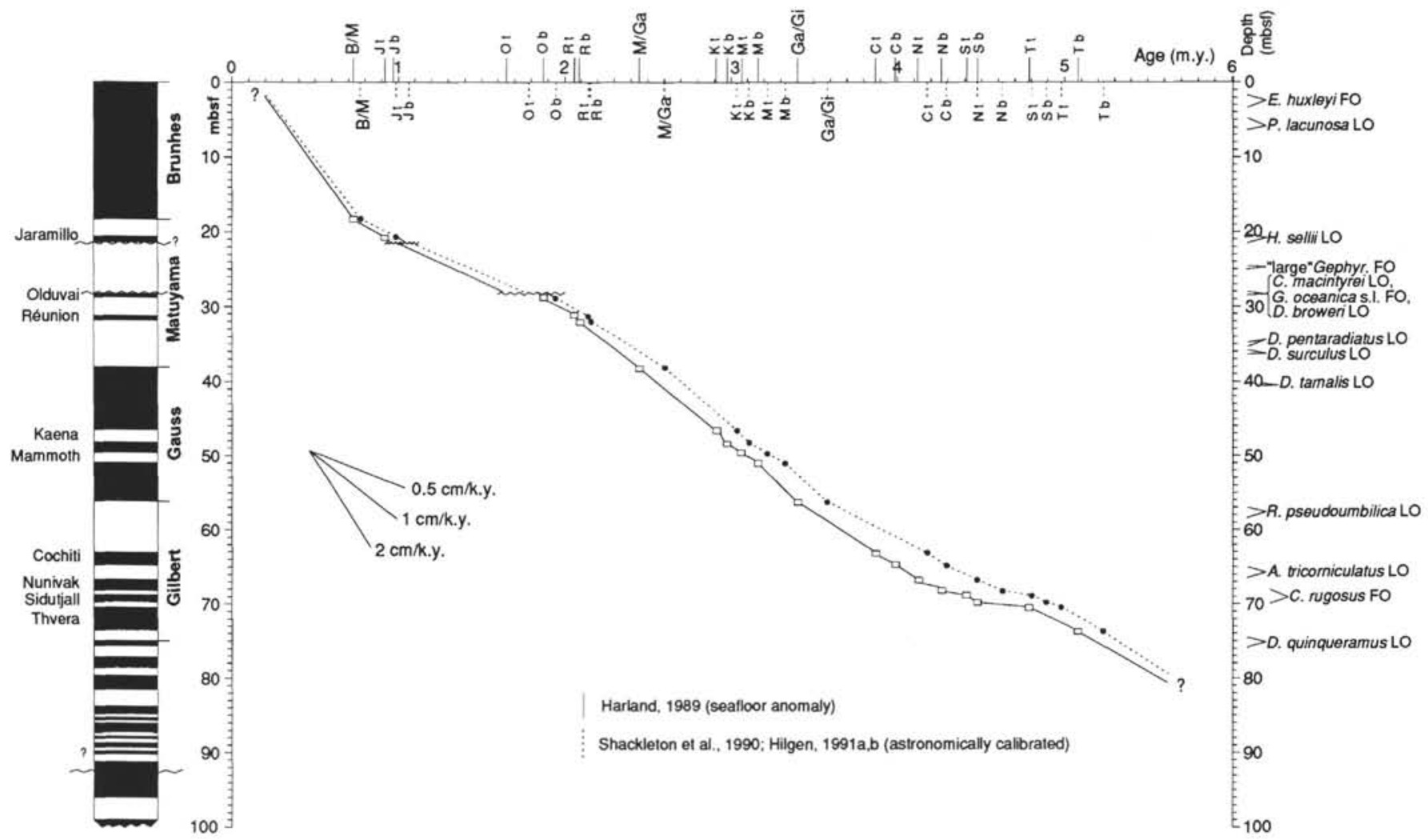

Figure 14. Sedimentation rate curve of the Neogene through Pleistocene in Hole 810C, based on two different magnetic reversal time scales (seafloor anomalies and "astronomic"). Positions of calcareous nannofossil events through depth are also included.

younger portion. About $99 \mathrm{~m}$ of sediments out of the total $136 \mathrm{~m}$ recovered in Hole $810 \mathrm{C}$ belong to the middle Miocene to upper Pleistocene interval. The succession is interrupted by three major hiatuses that removed (1) the topmost part of the Maastrichtian through the entire lower Paleocene and possibly the base of the upper Paleocene; (2) most of the lower Eocene, with a little portion of the uppermost Paleocene (Zone P5) reworked in younger lower Eocene sediments; and (3) the entire middle Eocene through most of the middle Miocene.

Three minor hiatuses are also inferred in the upper portion of the sequence mainly on the basis of calcareous nannofossils. They fall (1) between the middle and upper Miocene, removing Zone CN7; (2) across the Pliocene/Pleistocene boundary; and (3) at the top of the $H$. sellii Zone.

Severe reworking and displacement affected the lower part of the succession from the Maastrichtian through the middle Miocene. Reworking and displacement gradually decrease in the upper portion. These features are better expressed by the planktonic and benthic foraminifers than the calcareous nannofossils.

Two major dissolution episodes were detected in the Hole $810 \mathrm{C}$ succession as supported by the light weight percentage of the washed residues in comparison with the weight of the raw samples. They occur in the Maastrichtian and from the middle Miocene to upper Pliocene, but dissolution seems to have affected only the planktonic foraminifers, whereas calcareous nannofossils display relatively good preservation throughout.

Finally, the Pliocene-Pleistocene sequence recovered from Hole $810 \mathrm{C}$ is remarkably almost complete. The nannofossil succession allowed us to calibrate precisely the magnetic reversal sequence of the Pliocene through the middle Pleistocene (see Fig. 15). Moreover, the two minor hiatuses detected by calcareous nannofossils at the Pliocene/Pleistocene boundary and in the lower Pleistocene are also expressed in the shortening of the Olduvai and Jaramillo magnetic
Events within the Matuyama Chron. Planktonic foraminifers contributed little to this calibration because of poor preservation and low biostratigraphic resolution in this interval.

\section{ACKNOWLEDGMENTS}

The senior author is indebted to ODP for inviting her to participate in Leg 132. The authors would like to thank W.V. Sliter for his scientific support during the cruise, to I. Raffi for the fruitful discussions on calcareous nannofossil biostratigraphy, and to S. Gartner and J.V. Firth for their careful review. Participation on the cruise was supported by the Italian Consiglio Nazionale delle Ricerche (CNRECOD Program). This study received a financial support from the Italian Ministero dell' Università e della Ricerca Scientifica e Tecnologica (MURST-40\% to IPS).

\section{REFERENCES}

Berggren, W.A., 1973. The Pliocene time scale: calibration of planktonic foraminifera and calcareous nannoplankton zones. Nature, 243:391-397.

Blow, W.H., 1969. Late middle Eocene to Recent planktonic foraminiferal biostratigraphy. In Brönniman, P., and Renz, H.H. (Eds.), Proc. First Int. Conf. Planktonic Microfossils, Geneva, 1967: Leiden (E.J. Brill), 1:199-422. W.H., 1979. The Cainozoic Globigerinida: Leiden (E.J. Brill).

Boersma, A., and Premoli-Silva, I., 1983. Paleocene planktonic foraminiferal biogeography and the paleoceanography of the Atlantic Ocean. Micropaleontology, 29:355-381.

Boersma, A., Premoli Silva, I., and Shackleton, N.J., 1987. Atlantic Eocene planktonic foraminiferal paleohydrographic indicators and stable isotope paleoceanography. Paleoceanography, 2:287-331.

\footnotetext{
Abbreviations for names of organizations and publications in ODP reference lists follow the style given in Chemical Abstracts Service Source Index (published by American Chemical Society).
} 
Brönnimann, P., and Resig, J., 1971. A Neogene globigerinacean biochronologic time-scale of the Southwestern Pacific. In Winterer, E.L., Riedel, W.R., et al., Init. Repts. DSDP, 7 (Pt. 2): Washington (U.S. Govt. Printing Office), 1235-1469.

Caron, M., 1985. Cretaceous planktic foraminifera. In Bolli, H.M., Saunders, J.B., and Perch-Nielsen, K. (Eds.), Plankton Stratigraphy: Cambridge (Cambridge Univ. Press), 17-86.

Fleisher, R.L., 1974. Cenozoic planktonic foraminifera and biostratigraphy, Arabian Sea, Deep Sea Drilling Project, Leg 23A. In Whitmarsh, R.B. Weser, O.E., Ross, D.A., et al., Init. Repts. DSDP, 23: Washington (U.S. Govt. Printing Office), 1001-1072.

Gartner, S., 1977. Calcareous nannofossil biostratigraphy and revised zonation of the Pleistocene. Mar. Micropaleontol., 2:1-25.

Harland, W.B., Armstrong, R.L., Cox, A.V., Craig, L.E., Smith, A.G., and Smith, D.G., 1989. A Geologic Time Scale 1989: Cambridge (Cambridge Univ. Press).

Hilgen, F.J., 1991a. Astronomical calibration of Gauss to Matuyama sapropels in the Mediterranean and implication for the Geomagnetic Polarity Time Scale. Earth Planet. Sci. Lett., 104:226-244.

1991b. Extension of the astronomically calibrated (polarity) time scale to the Miocene/Pliocene boundary. Earth Planet. Sci. Lett., 107:349-368.

Kennett, J.P., and Srinivasan, M.S., 1983. Neogene Planktonic Foraminifera: A Phylogenetic Atlas: Stroudsburg, PA (Hutchinson Ross).

Okada, H., and Bukry, D., 1980. Supplementary modification and introduction of code numbers to the low-latitude coccolith biostratigraphic zonation (Bukry, 1973; 1975). Mar. Micropaleontol., 5:321-325.

Olsson, R.K., Hemleben, C., Berggren, W.A., and Liu, C., 1992. Wall texture classification of planktonic Foraminifera Genera in the lower Danian. $J$. Foraminiferal Res., 22:195-213.

Perch-Nielsen, K., 1981. New Maastrichtian and Paleocene calcareous nannofossils from Africa, Denmark, the USA and the Atlantic, and some Paleocene lineages. Eclogae Geol. Helv., 74:831-863.

Premoli Silva, I., and Boersma, A., 1977. Cretaceous planktonic foraminifersDSDP Leg 39 (South Atlantic). In Perch-Nielsen, K., Supko, P.R., et al., Init. Repts. DSDP, 39: Washington (U.S. Govt. Printing Office), 615-641.

- 1988. Atlantic Eocene planktonic foraminiferal historical biogeography and paleohydrographic indices. Palaeogeogr., Palaeoclimatol., Palaeoecol., 67:315-356.

Premoli Silva, I., and Violanti, D., 1981. Cenozoic planktonic-foraminifer biostratigraphy of Deep Sea Drilling Program Hole 462, Nauru Basin (western equatorial Pacific) and distribution of the pelagic components. In Larson, R.L., Schlanger, S.O., et al., Init. Repts. DSDP, 61: Washington (U.S. Govt. Printing Office), 397-422.

Raffi, I., Backmann, J., Rio, D., and Shackleton, N.J., in press. Early Pleistocene and late Pliocene nannofossil biostratigraphy and calibration to oxygen isotope stratigraphies from DSDP Site 607 and ODP Site 677. Paleoceanography.

Raffi, I., and Rio, D., 1979. Calcareous nannofossil biostratigraphy of DSDP Site 132-Leg 13 (Tyrrhenian Sea-Western Mediterranean). Riv. Ital. Paleontol. Stratigr., 85:127-172.

Rio, D., 1982. The fossil distribution of coccolithophore genus Gephyrocapsa Kamptner and related Plio-Pleistocene chronostratigraphic problems. In Prell, W.L., Gardner, J.V., et al., Init. Repts. DSDP, 68: Washington (U.S. Govt. Printing Office), 325-343.

Rio, D., Raffi, I., and Villa, G., 1990. Pliocene-Pleistocene calcareous nannofossil distribution patterns in the Western Mediterranean. In Kastens, K.A., Mascle, J., et al., Proc. ODP, Sci. Results, 107: College Station, TX (Ocean Drilling Program), 513-533.

Rio, D., Sprovieri, R., Di Stefano, E., and Raffi, I., 1984. Globorotalia truncatulinoides (d'Orbigny) in the Mediterranean upper Pliocene geologic record. Micropaleontology, 30:121-137.

Rio, D., Sprovieri, R., and Thunell, R., 1991. Pliocene-lower Pleistocene chronostratigraphy: a re-evaluation of Mediterranean type sections. Geol. Soc. Am. Bull., 103:1049-1058.

Robaszynski, F., Caron, M., Gonzales-Donoso, J.-M., and Wonders, A.A.H., 1984. Atlas of Late Cretaceous planktonic foraminifera. Rev. Micropaleontol., 26:145-305.

Shackleton, N.J., Berger, A., and Peltier, W.R., 1990. An alternative astronomical calibration of the lower Pleistocene timescale based on ODP Site 677. Trans. R. Soc. Edinburgh, Earth Sci., 81:251-261.

Sliter, W.V., 1989. Biostratigraphic zonation for Cretaceous planktonic foraminifers examined in thin section. J. Foraminiferal Res., 19:1-19.
Spezzaferri, S., 1992. Il limite Oligocene/Miocene nel "record oceanico" (Atlantico, Indiano, Sud Pacifico): biostratigrafia e paleoclimatotologia [Ph.D. dissert.]. Milan, Univ. of Milan.

Storms, M.A., Natland, J.H., et al., 1991. Proc. ODP, Init. Repts., 132: College Station, TX (Ocean Drilling Program).

Thierstein, H.R., Geitzenauer, K., Molfino, B., and Shackleton, N.J., 1977. Global synchroneity of late Quaternary coccolith datum levels: validation by oxygen isotopes. Geology, 5:400-404.

Toumarkine, M., and Luterbacher, H.P., 1985. Paleocene and Eocene planktic foraminifera. In Bolli, H.M., Saunders, J.B., and Perch-Nielsen, K. (Eds.), Plankton Stratigraphy: Cambridge (Cambridge Univ. Press), 87-154.

Vincent, E., 1975. Neogene planktonic foraminifera from the Central North Pacific, Leg 32, Deep Sea Drilling Project. In Larson, R.L., Moberly, R., et al., Init. Repts. DSDP, 32: Washington (U.S. Govt. Printing Office), $765-801$.

\section{Date of initial receipt: 16 November 1992 \\ Date of acceptance: 22 April 1993 \\ Ms 132SR-305}

\section{APPENDIX}

\section{Planktonic Foraminifers}

Planktonic foraminifers are arranged in alphabetic order per genus and per species.

\section{List of Cretaceous Species}

Abathomphalus intermedius (Bolli, 1951) (= Globotruncana intermedia Bolli)

Abathomphalus mayaroensis (Bolli, 1951) (= Globotruncana mayaroensis Bolli)

Archaeoglobigerina blowi Pessagno, 1967

Archaeoglobigerina cretacea (d'Orbigny, 1840) (= Globigerina cretacea d'Orbigny)

Contusotruncana contusa (Cushman, 1926) (= Pulvinulina arca var. contusa Cushman)

Contusotruncana fornicata (Plummer, 1921) (= Globotruncana fornicata Plummer)

Contusotruncana patelliformis (Gandolfi, 1955) (= Globotruncana patelliformis Gandolfi)

Contusotruncana plummerae (Gandolfi, 1955) (= Globotruncana plummerae Gandolfi)

Contusotruncana walfischensis $($ Todd, 1970) $(=$ Globotruncana walfischensis Todd)

Gansserina wiedenmayeri (Gandolfi, 1955) (= Globotruncana wiedenmayeri Gandolfi)

Globigerinelloides alvarezi (Eternod Olvera, 1959) (= Planomalina alvarezi Eternod Olvera)

Globigerinelloides messinae (Brönnimann, 1952) (= Globigerinella messinae Brönnimann)

Globigerinelloides prairiehillensis Pessagno, 1967

Globigerinelloides subcarinatus (Brönnimann, 1952) $(=$ Globigerinella messinae subcarinata Brönnimann)

Globotruncana aegyptiaca Nakkady, 1950

Globotruncana arca (Cushman, 1926) (= Pulvinulina arca Cushman)

Globotruncana bulloides Vogler, 1941

Globotruncana dupeublei Caron, Gonzales Donoso, Robaszynski, and Wonders, 1984

Globotruncana falsostuarti Sigal, 1952

Globotruncana lapparenti Brotzen, 1936

Globotruncana linneiana (d'Orbigny, 1839) (= Rosalina linneiana d'Orbigny)

Globotruncana orientalis El Naggar, 1966

Globotruncana rosetta (Carsey, 1926) (= Globigerina rosetta Carsey)

Globotruncana ventricosa White, 1928

Globotruncanella havanensis (Voorwijk, 1937) $(=$ Globotruncana havanensis Voorwijk)

Globotruncanella minuta Caron and Gonzales Donoso, 1984 
Globotruncanella petaloidea (Gandolfi, 1955) (= Globotruncana (Rugoglobigerina) petaloidea Gandolfi)

Globotruncanella pschadae (Keller, 1946) (= Globorotalia pschadae Keller) Globotruncanita atlantica (Caron, 1972) (= Globotruncana atlantica Caron) Globotruncanita conica (White, 1928) (= Globotruncana conica White)

Globotruncanita elevata (Brotzen, 1934) (= Rotalia elevata Brotzen)

Globotruncanita pettersi (Gandolfi, 1955) (= Globotruncana rosetta pettersi Gandolfi)

Globotruncanita stuarti (de Lapparent, 1918) (= Rosalina stuarti de Lapparent)

Globotruncanita stuartiformis (Dalbiez, 1955) (= Globotruncana stuartiformis Dalbiez)

Gublerina acuta de Klasz, 1953

Gublerina cuvillieri Kikoine, 1948

Hedbergella holmdelensis Olsson, 1964

Hedbergella monmouthensis (Olsson, 1960) (= Globorotalia monmouthensis Olsson)

Heterohelix globulosa (Ehrenberg, 1840) (= Textularia globulosa Ehrenberg)

Heterohelix navarroensis Loeblich, 1951

Heterohelix pulchra (Brotzen, 1936) (= Guembelina pulchra Brotzen)

Heterohelix punctulata (Cushman, 1938) (= Guembelina punctulata Cushman)

Heterohelix rajagopalani (Govindan, 1972) (= Gublerina rajagopalani Govindan)

Heterohelix striata (Ehrenberg, 1840) (= Textularia striata Ehrenberg)

Planoglobulina acervulinoides (Egger, 1899) (= Guembelina acervulinoides Egger)

Planoglobulina carseyae (Plummer, 1931) (= Ventilabrella carseyae Plummer)

Planoglobulina multicamerata de Klasz, 1953

Pseudoguembelina costulata (Cushman, 1938) (= Guembelina costulata Cushman)

Pseudoguembelina excolata (Cushman, 1926) (= Guembelina excolata Cushman)

Pseudoguembelina palpebra Brönnimann and Brown, 1953

Pseudotextularia elegans (Rzehak, 1891) (= Cuneolina elegans Rzehak)

Racemiguembelina fructicosa (Egger, 1899) (= Guembelina fructicosa Egger)

Rugoglobigerina hexacamerata Brönnimann, 1952

Rugoglobigerina macrocephala Brönnimann, 1952

Rugoglobigerina reicheli Brönnimann, 1952

Rugoglobigerina rugosa (Plummer, 1926) (= Globigerina rugosa Plummer)

Rugotruncana subcircumnodifer (Gandolfi, 1955) (= Globotruncana (Rugoglobigerina) circumnodifer subcircumnodifer Gandolfi)

Rugotruncana subpenneyi (Gandolfi, 1955) (= Globotruncana (Rugoglobigerina) penneyi subpenneyi Gandolfi)

Schakoina multispinata (Cushman and Wickenden, 1930) (= Hantkenina multispinata Cushman and Wickenden)

Schakoina sp.

Trinitella scotti Brönnimann, 1952

Ventilabrella eggeri Cushman, 1928

List of Paleocene and Eocene Species

Acarinina bullbrooki (Bolli, 1957) (= Globorotalia bullbrooki Bolli)

Acarinina collactea (Finlay, 1939) (= Globorotalia collactea Finlay)

Acarinina decepta (Martin, 1943) (= Globigerina decepta Martin)

Acarinina esnaensis (LeRoy, 1953) (= Globigerina esnaensis LeRoy)

Acarinina nitida (Martin, 1943) (= Globigerina nitida Martin)

Acarinina pentacamerata Subbotina, 1953

Acarinina primitiva (Finlay, 1939) (= Globoquadrina primitiva Finlay)

Acarinina pseudotopilensis Subbotina, 1953

Acarinina rohri (Brönnimann and Bermudez, 1953) (= Truncorotaloides rohri Bronnimann and Bermudez)

Acarinina rotundimarginata Subbotina, 1953

Acarinina rugosoaculeata Subbotina, 1953

Acarinina soldadoensis (Brönnimann, 1952) (= Globigerina soldadoensis Brönnimann)

Acarinina soldadoensis angulosa (Bolli, 1957) (= Globigerina soldadoensis Brönnimann subsp. angulosa Bolli)

Eoglobigerina edita (Subbotina, 1953) (= Globigerina edita Subbotina)

Globanomalina compressa (Plummer, 1926) (= Globigerina compressa Plummer)

Globanomalina ehrenbergi (Bolli, 1957) (= Globorotalia ehrenbergi Bolli)
Globanomalina planoconica (Subbotina, 1953) (= Globorotalia planoconica Subbotina)

Globanomalina pseudoscitula (Glaessner, 1937) (= Globorotalia pseudoscitula Glaessner)

"Globigerinatheka" senni (Beckmann, 1953) (= Sphaeroidinella senni Beckmann)

Globigerinatheka subconglobata micra (Shutskaya, 1958) (= Globigerinoides subconglobatus var. micra Shutskaya)

Globoconusa daubjergensis (Brönnimann, 1953) (= Globigerina daubjergensis Brönnimann)

Guembelitrioides higginsi (Bolli, 1957) (= "Globigerinoides" higginsi Bolli)

Morozovella abundocamerata (Bolli, 1957) (= Globorotalia abundocamerata Bolli)

Morozovella acuta (Toulmin, 1941) (= Globorotalia wilcoxensis var. acuta Toulmin)

Morozovella aequa (Cushman and Renz, 1942) (= Globorotalia crassata (Cushman) var. aequa Cushman and Renz)

Morozovella angulata (White, 1928) (= Globigerina angulata White)

Morozovella aragonensis (Nuttall, 1930) (= Globorotalia aragonenis Nuttall)

Morozovella caucasica (Glaessner, 1937) (= Globorotalia caucasica Glaessner)

Morozovella conicotruncata (Subbotina, 1947) (= Globorotalia conicotruncata Subbotina)

Morozovella crassata (Cushman, 1925) (= Pulvinulina crassata Cushman)

Morozovella gracilis (Bolli, 1957) (= Globorotalia formosa gracilis Bolli)

Morozovella pusilla (Bolli, 1957) (= Globorotalia pusilla pusilla Bolli)

Morozovella simulatilis (Schwager, 1883) (=Discorbina simulatilis Schwager)

Morozovella subbotinae (Morozova, 1939) (= Globorotalia subbotinae Morozova)

Morozovella velascoensis (Cushman, 1925) (= Pulvinulina velascoensis Cushman)

Muricoglobigerina mckannai (White, 1928) (= Globigerina mckannai White)

Parasubbotina pseudobulloides (Plummer, 1926) (= Globigerina pseudobulloides Plummer)

Parasubbotina varianta (Subbotina, 1953) (= Globigerina varianta Subbotina)

Parvularugoglobigerina eugubina (Luterbacher and Premoli Silva, 1964) (= Globigerina eugubina Luterbacher and Premoli Silva)

Praemurica inconstans (Subbotina, 1953) (= Globigerina inconstans Subbotina)

Praemurica praecursoria (Morozova, 1957) (= Acarinina praecursoria Morozova)

Praemurica trinidadensis (Bolli, 1957) (= Globorotalia trinidadensis Bolli)

Praemurica uncinata (Bolli, 1957) (= Globorotalia uncinata Bolli)

Pseudohastigerina danvillensis (Howe and Wallace, 1932) (=Nonion danvillensis Howe and Wallace)

Pseudohastigerina micra (Cole, 1927) (= Nonion micrus Cole)

Pseudohastigerina wilcoxensis (Cushman and Ponton, 1932) (=Nonion wilcoxensis Cushman and Ponton)

Subbotina cruciapertura Blow, 1979

Subbotina eocaenica (Terquem, 1882) (= Globigerina eocaenica Terquem)

Subbotina triloculinoides (Plummer, 1926) (= Globigerina triloculinoides Plummer)

Truncorotaloides topilensis (Cushman, 1925) (= Globigerina topilensis Cushman)

Turborotalia frontosa (Subbotina, 1953) (= Globigerina frontosa Subbotina)

List of Neogene Species

Beella digitata (Brady, 1879) (= Globigerina digitata Brady)

Beella praedigitata (Parker, 1967) (= Globigerina praedigitata Parker)

Candeina nitida d'Orbigny, 1839

Dentoglobigerina altispira altispira (Cushman and Jarvis, 1936) (= Globigerina altispira Cushman and Jarvis)

Dentoglobigerina larmeui (Akers, 1955) (= Globoquadrina larmeui Akers)

Globigerina bulbosa LeRoy, 1944

Globigerina bulloides d'Orbigny, 1926

"Globigerina" conglomerata Schwager, 1866

Globigerina eamesi Blow, 1959

Globigerina falconensis Blow, 1959

Globigerina palpebra (Brönnimann and Resig, 1971) (= Globorotalia palpebra Brönnimann and Resig)

"Globigerina" quinqueloba Natland, 1938 
"Globigerina" venezuelana Hedberg, 1937

Globigerinella calida (Parker 1962) (= Globigerina calida Parker)

Globigerinella obesa (Bolli, 1957) (= Globorotalia obesa Bolli)

Globigerinella siphonifera (d'Orbigny, 1839) (= Hastigerina siphonifera d'Orbigny)

Globigerinita glutinata (Egger, I893) (= Globigerina glutinata Egger)

Globigerinita juvenilis (Bolli, 1957) (= Globigerina juvenilis Bolli)

Globigerinita parkerae (Bermudez, 1961) (= Globigerinoides parkerae Bermudez)

Globigerinita uvula (Ehrenberg, 1861) (= Pylodexia uvula Ehrenberg)

Globigerinoides bollii Blow, 1959

Globigerinoides conglobatus (Brady, 1879) $(=$ Globigerina conglobata Brady)

Globigerinoides cyclostomus (Galloway and Wissler, 1927) (= Globigerina cyclostoma Galloway and Wissler)

Globigerinoides elongatus (d'Orbigny, 1826) (= Globigerina elongata d'Orbigny)

Globigerinoides extremus Bolli and Bermudez, 1957 (= Globigerinoides obliquus Bolli subsp. extremus Bolli and Bermudez)

Globigerinoides gomitulus (Seguenza, 1880) (= Globigerina gomitulus Seguenza)

Globigerinoides obliquus Bolli, 1957

Globigerinoides pyramidalis (Van den Broeck, 1876) (= Globigerinoides ruber var. pyramidalis Van den Broeck)

Globigerinoides quadrilobatus (d'Orbigny, 1846) (= Globigerina quadrilobata d'Orbigny)

Globigerinoides ruber (d'Orbigny, 1839) (= Globigerina rubra d'Orbigny)

Globigerinoides sacculifer (Brady, 1877) (= Globigerina sacculifera Brady)

Globigerinoides seigliei Bermudez and Bolli, 1969

Globigerinoides trilobus (Reuss, 1850) (= Globigerina triloba Reuss)

Globigerinoides tenellus Parker, 1958

Globoquadrina dehiscens (Chapman, Parr, and Collins, 1934) (= Globorotalia dehiscens Chapman, Parr, and Collins)

Globorotalia crassaformis crassaformis (Galloway and Weissler, 1927) (= Globigerina crassaformis Galloway and Weissler)

Globorotalia conoidea Walters, 1965 (= Globorotalia miozea conoidea Walters)

Globorotalia conomiozea Kennett, 1966

Globorotalia crassaformis oceanica Cushman and Bermudez, 1949 (= Globorotalia (Turborotalia) oceanica Cushman and Bermudez)

Globorotalia crassaformis viola Blow, 1969 (= Globorotalia (Globorotalia) crassula viola Blow)

Globorotalia crassula Cushman and Stewart, 1930

Globorotalia exilis Blow, 1969 (= Globorotalia cultrata exilis Blow)

Globorotalia hirsuta (d'Orbigny, 1839) (= Rotalina hirsuta d'Orbigny)

Globorotalia inflata (d'Orbigny, 1839) (= Globigerina inflata d'Orbigny)

Globorotalia margaritae Bolli and Bermudez, 1965

Globorotalia margaritae evoluta Cita, 1973

Globorotalia margaritae primitiva $\mathrm{Cita}, 1963$

Globorotalia menardii (Parker, Jones, and Brady, 1865) (= Rotalia menardii Parker, Jones, and Brady)

Globorotalia merotumida Blow and Banner, 1965

Globorotalia miozea Finlay, 1939

Globorotalia plesiotumida Blow and Banner, 1965

Globorotalia puncticulata (Deshayes, 1832) (= Globigerina puncticulata Deshayes)

Globorotalia scitula (Brady, 1882) (= Pulvinulina scitula Brady)

Globorotalia theyeri Fleisher, 1974

Globorotalia tumida (Brady, 1877) (= Pulvinulina menardii (d'Orbigny) var. tumida Brady)
Globorotalia tumida flexuosa $($ Koch, 1923) $(=$ Pulvinulina tumida Brady var. flexuosa $\mathrm{Koch}$ )

Globorotaloides hexagonus (Natland, 1938) (= Globigerina hexagona Natland)

Globorotaloides pseudofoliatus (Parker, 1967) (= Globoquadrina pseudofoliata Parker)

Neogloboquadrina humerosa (Takayanagi and Saito, 1962) $(=$ Globorotalia humerosa Takayanagi and Saito)

Neogloboquadrina acostaensis (Blow, 1959) (= Globorotalia acostaensis Blow)

Neogloboquadrina dutertrei (d'Orbigny, 1839) (= Globigerina dutertrei d'Orbigny)

Neogloboquadrina eggeri (Rhumbler, 1901) (= Globigerina eggeri Rhumbler)

Neogloboquadrina pachyderma (Ehrenberg, 1861) (= Aristospira pachyderma Ehrenberg)

Neogloboquadrina pseudopachyderma (Cita, Premoli Silva, and Rossi, 1965) (= Globorotalia pseudopachyderma Cita, Premoli Silva, and Rossi)

Neogloboquadrina pseudopima (Blow, 1969) (= Globorotalia (Turborotalia) acostaensis pseudopima Blow)

Orbulina bilobata (d'Orbigny, 1864) (= Globigerina bilobata d'Orbigny)

Orbulina suturalis Brönnimann, 195

Orbulina universa d'Orbigny, 1839

Paragloborotalia? laccadivensis (Fleisher, 1972) $(=$ Globanomalina laccadivensis Fleisher)

Pulleniatina finalis Banner and Blow, 1967

Pulleniatina obliquiloculata (Parker and Jones, 1865) (= Pullenia sphaeroides (d'Orbigny) var. obliquiloculata Parker and Jones)

Pulleniatina precursor Banner and Blow, 1967 (= Pulleniatina obliquiloculata (Parker and Jones) praecursor Banner and Blow)

Pulleniatina primalis Banner and Blow, 1967

Sphaeroidinella dehiscens (Parker and Jones, 1865) (= Sphaeroidina bulloides d'Orbigny var. dehiscens Parker and Jones)

Sphaeroidinella dehiscens excavata Banner and Blow, 1965

Sphaeroidinellopsis kochi (Caudri, 1934) (= Globigerina kochi Caudri)

Sphaeroidinellopsis paenedehiscens Blow, 1969

Sphaeroidinellopsis seminulina (Schwager, 1866) (= Globigerina seminulina Schwager)

Streptochilus pristinum Brönnimann and Resig, 1971

Tenuitella anfracta (Parker, 1967) (= Globorotalia anfracta Parker)

Tenuitella neoclemenciae $\mathrm{Li}, 1987$

Tenuitellinata iota (Parker, 1962) (= Globigerinita iota Parker)

Truncorotalia tosaensis tenuiteca (Blow, 1969) $(=$ Globorotalia (Turborotalia) tosaensis tenuiteca Blow)

Truncorotalia tosaensis tosaensis (Takayanagi and Saito, 1962) $(=$ Globorotalia tosaensis Takayanagi and Saito)

Truncorotalia truncatulinoides (d'Orbigny, 1839) (= Rotalia truncatulinoides d'Orbigny)

Truncorotalia truncatulinoides excelsa (Sprovieri, Ruggeri, and Unti, 1980) (= Globorotalia truncatulinoides excelsa Sprovieri, Ruggeri, and Unti)

Turborotalita humilis (Brady, 1884) (= Truncatulina humilis Brady)

Turborotalita rubescens (Hofker, 1956) (= Globigerina rubescens Hofker)

Zeaglobigerina decoraperta (Takayanagi and Saito, 1962) (= Globigerina decoraperta Takayanagi and Saito)

Zeaglobigerina incisa (Brönnimann and Resig, 1971) (= Globorotalia incisa Brönnimann and Resig)

Zeaglobigerina microstoma (Cita, Premoli Silva, and Rossi, 1965) (= Globigerina microstoma Cita, Premoli Silva, and Rossi)

Zeaglobigerina nepenthes (Todd, 1957) (= Globigerina nepenthes Todd)

Zeaglobigerina woodi (Jenkins, 1960) (= Globigerina woodi Jenkins) 


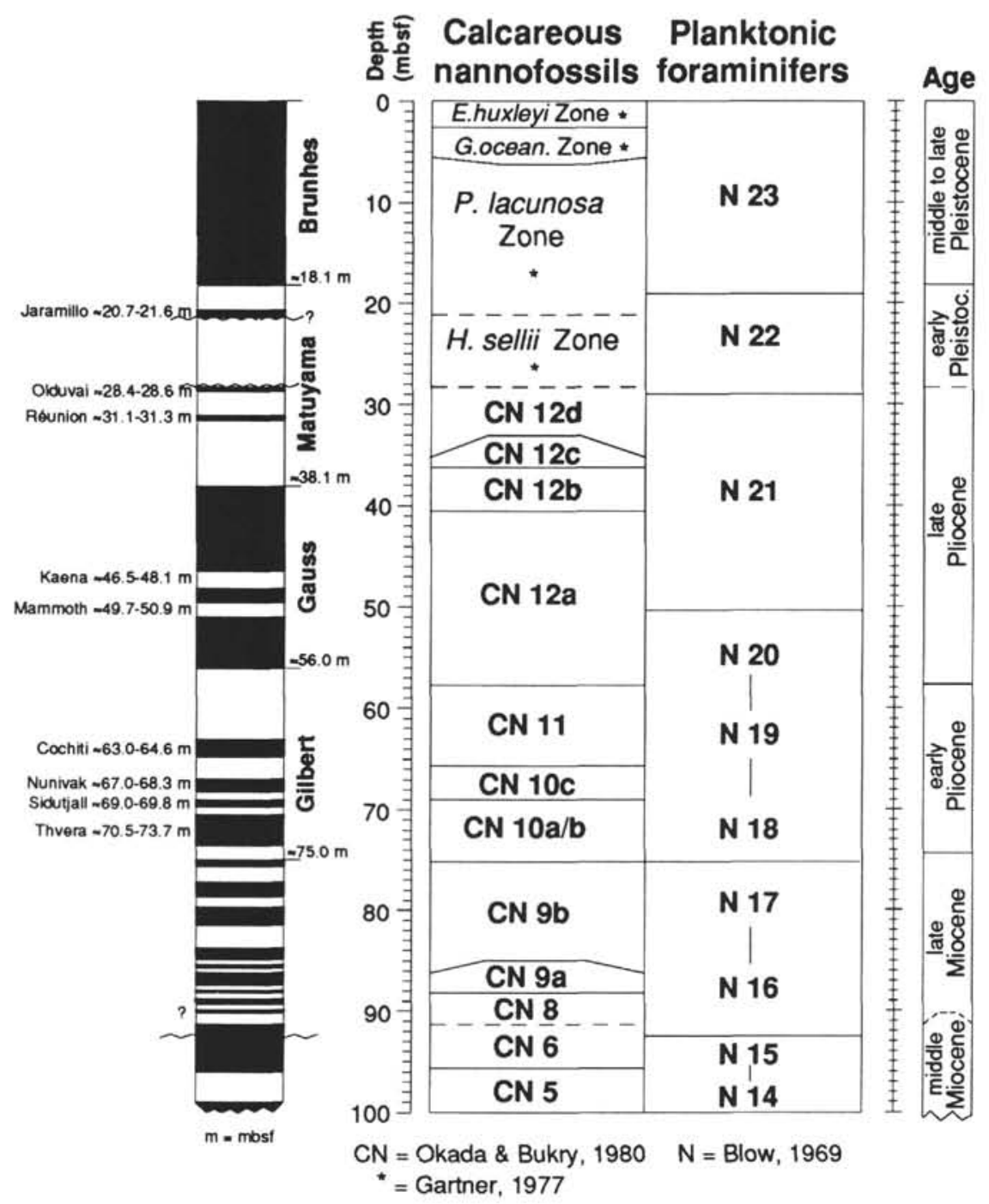

Figure 15. Biostratigraphic and magnetostratigraphic summary of Neogene to Pleistocene sequence recovered in Hole 810C. 


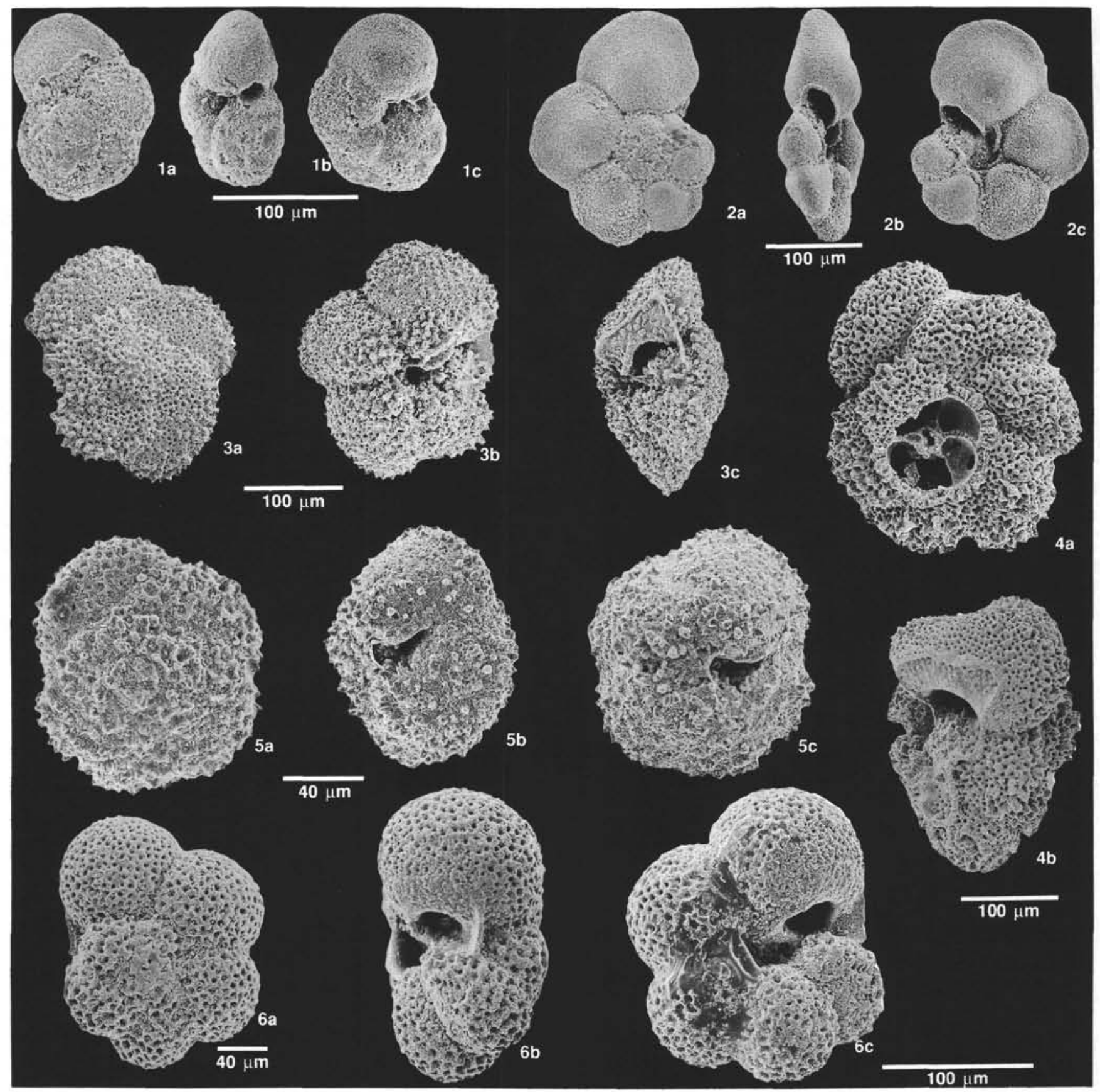

Plate 1. 1a-c. Globanomalina compressa (Plummer), Sample 132-810C-13H-2, 21-22 cm. 2a-c. Globanomalina ehrenbergi (Bolli, Sample 132-810C13H-2, 21-22 cm. 3a-c. Morozovella simulatilis (Schwager), Sample 132-810C-13H-2, 21-22 cm (a, spiral view; b, umbilical view; c, side view). 4a-b. Morozovella abundocamerata (Bolli), Sample 132-810C-13H-2, 21-22 cm. 5a-c. Morozovella pusilla (Bolli), Sample 132-810C-13H-2, 21-22 cm. 6a-c. Eoglobigerina edita (Subbotina), Sample 132-810C-13H-2, 21-22 cm (a, spiral view; b, side view; c, umbilical view. 


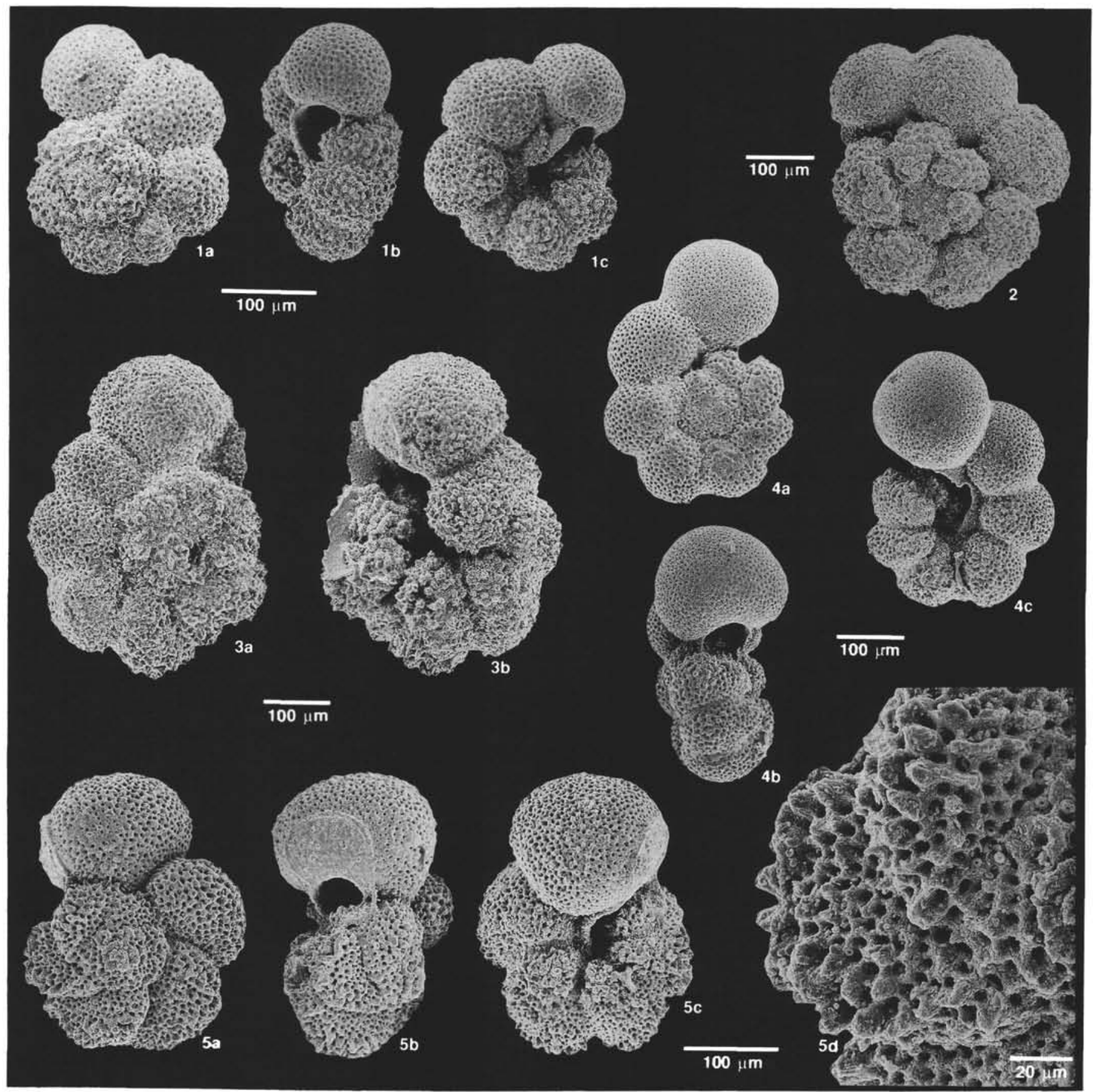

Plate 2. 1a-c. Praemurica inconstans (Subbotina), Sample 132-810C-13H-4, 22-23 cm. 2. Praemurica inconstans (Subbotina), Sample 132-810C-13H-4, 22-23 cm. 3a-b. Praemurica praecursoria (Morozova), Sample 132-810C-13H-4, $137 \mathrm{~cm}$ (a, spiral view; b, umbilical view). 4a-c. Praemurica trinidadensis (Bolli), Sample 132-810C-13H-4, 22-23 cm. 5a-d. Praemurica uncinata (Bolli), Sample 132-810C-13H-4, 22-23 cm (a, spiral view; b, side view; c, umbilical view; d, detail of the wall texture except when differently specified). 